\title{
42. QUATERNARY BIOSTRATIGRAPHY AND SURFACE PALEOTEMPERATURES BASED ON PLANKTONIC FORAMINIFERS ${ }^{1}$
}

\author{
Max S. Barash and Natalia S. Oskina, P. P. Shirshov Institute of Oceanology, \\ Academy of Sciences, Moscow, U.S.S.R. \\ and \\ Natalia S. Blyum, Moscow State University, Moscow, U.S.S.R.
}

\begin{abstract}
Quantitative analysis was performed on the Quaternary planktonic foraminiferal fauna from Site 516, near the crest of the Rio Grande Rise, and Site 518, on the lower western flank of the Rise. From Hole 516, 46 samples were taken, and from Hole 518, 80 samples were taken. The mean interval between samples is 20 to $25 \mathrm{~cm}$. About 50 species of Quaternary and Pliocene planktonic foraminifers were identified. Quaternary sediments, dated by the initial evolutionary appearance of Globorotalia truncatulinoides and other criteria, have thickness of $9.8 \mathrm{~m}$ in Hole 516 and $16 \mathrm{~m}$ in Hole 518 .

The Globorotalia truncatulinoides Zone is subdivided into four subzones or biostratigraphic horizons (from lower to upper): (1) Globorotalia crassaformis viola, (2) Globorotalia crassaformis hessi, (3) Globigerina calida calida, and (4) Globigerinoides ruber (pink). Thickness of these horizons in Hole 516 establishes the age of the boundaries between them as $1.47,0.81$, and $0.28 \mathrm{Ma}$, respectively.

All the Quaternary planktonic foraminiferal complexes sampled are subtropical. The region of the Rio Grande Rise, therefore, has been within the southern subtropical gyre continuously for the last $2 \mathrm{Ma}$.

The average annual surface water temperatures were reconstructed for the Quaternary at both sites. A micropaleontologic method for the paleotemperature analysis of the thanatocoenosis registers an average Quaternary temperature of $21.2^{\circ} \mathrm{C}$ at Site 516 and $21.7^{\circ} \mathrm{C}$ at Site 518 . The temperature fluctuations increase up to $3.5^{\circ} \mathrm{C}$ during the accumulation of the two last horizons (since $0.81 \mathrm{Ma}$ ). Temperature peaks are tentatively compared with oxygen isotopic stages and with continental glaciations. Levels at which planktonic foraminiferal species disappear correspond to coldwater intervals.

In the Quaternary of Site 518, some layers show signs of dissolution. Corrosive to $\mathrm{CaCO}_{3}$, the northward flow of Antarctic Bottom Water through the Vema Channel increases during the cold periods. Site 518 has two layers of redeposited foraminiferal sand with Pliocene foraminifers. The average rate of the Quaternary sedimentation in Hole 516 is $0.52 \mathrm{~cm}$ per thousand years, and in Hole 518 it is $0.84 \mathrm{~cm}$ per thousand years.
\end{abstract}

\section{INTRODUCTION}

During Glomar Challenger DSDP Leg 72, four sites were drilled in the South Atlantic in the Rio Grande Rise region: Site 515 in the Brazil Basin, Site 516 near the crest of the Rio Grande Rise, and Sites 517 and 518 on the lower western flank of the Rise (Barker et al., 1981). Sites 516 and 518 were selected for analysis in the present report.

Site $516\left(30^{\circ} 16.58^{\prime} \mathrm{S}, 35^{\circ} 17.11^{\prime} \mathrm{W}, 1313 \mathrm{~m}\right.$ water depth) resulted in the recovery of $1250 \mathrm{~m}$ of predominantly biogenic calcareous sediments and $21 \mathrm{~m}$ of basaltic basement rocks of Santonian-Coniacian age. Sedimentation at this site was continuous for the past 80 m.y., with the exception of some narrow hiatuses in the middle and late Miocene. An upper unit of the lower Miocene to Holocene sediment, 205 m thick, consists of foraminiferal and nannofossil oozes and is $80-90 \%$ $\mathrm{CaCO}_{3}$. Their accumulation at the relatively shallow depth near the crest of the Rise accounts for the perfect preservation of planktonic foraminifers. This good preservation provides for detailed biostratigraphic and paleotemperature reconstructions.

\footnotetext{
${ }^{1}$ Barker, P. F., Carlson, R. L., Johnson, D. A., et al., Init. Repts. DSDP, 72: Washing ton (U.S. Govt. Printing Office).
}

Site $518\left(29^{\circ} 58.42^{\prime} \mathrm{S}, 38^{\circ} 08.12^{\prime} \mathrm{W}, 3944 \mathrm{~m}\right.$ water depth) recovered $71.9 \mathrm{~m}$ of lower Miocene to upper Pleistocene deposits. The upper $54 \mathrm{~m}$ of the sediment are foraminiferal and nannofossil ooze with interlayers of foraminiferal sands (upper Miocene to Quaternary). This site also provides data for detailed biostratigraphic and paleotemperature reconstructions. The site occupies the eastern flank of the Vema Channel through which Antarctic Bottom Water (AABW) enters the Brazil Basin.

In the depth interval 4000-4200 $\mathrm{m}$ (that is, deeper than Site 518) is a transition zone between the North Atlantic Deep Water (NADW) and AABW. The vertical fluctuations of the transition zone and pulses of AABW during the Pleistocene should have affected the preservation of the planktonic foraminiferal assemblages and the abundance of their tests in the sediment. In this paper, we investigate whether the temperature fluctuations of the surface water correlate with pulses of AABW flow through the Vema Channel.

\section{METHODS}

\section{Laboratory Treatment}

Samples were dried at room temperature and weighed. Then they were immersed in water and washed through a set of 0.1-mm and $0.05-\mathrm{mm}$ sieves. The resulting granulometric fractions were divided in- 
to three groups: coarser than $0.1 \mathrm{~mm}$, between 0.1 and $0.05 \mathrm{~mm}$, and finer than $0.05 \mathrm{~mm}$; all the fractions were then dried.

For foraminiferal analyses we used the group of fractions coarser than $0.1 \mathrm{~mm}$, which consisted almost entirely of planktonic foraminiferal tests. The fractions were thoroughly mixed and divided until the remaining split contained at least 300 tests. All components were identified and counted in this split according to the Quaternary species taxonomy of Bé (1977) and the Tertiary species taxonomy of Parker (1967). Additionally, all the size fractions greater than $0.1 \mathrm{~mm}$ were thoroughly examined under microscope to discover rare species that might be omitted from the split.

Percentages of all planktonic foraminiferal species and planktonic-benthic foraminiferal ratios were computed. The "foraminiferal number"' (the number of shells larger than $0.1 \mathrm{~mm}$ per $1 \mathrm{~g}$ of dry sediment) was then calculated.

\section{Micropaleontologic Paleotemperature Analysis}

Using planktonic foraminiferal tests contained in sediment it is possible to reconstruct the climatic regime of the geologic past, if we know the connections between the planktonic foraminiferal distribution, climatic zonation, temperature and other properties of the upper oceanic layer. Quantitative correlation, established between water temperature and the distribution of planktonic foraminiferal tests in the Recent sediment, permits the reconstruction of paleotemperatures for at least the entire Pleistocene.

In the early sixties, Barash $(1964,1970)$ worked out methods for a quantitative analysis of paleotemperature according to the structure of thanatocoenoses of planktonic foraminifers within the range of the average annual temperature in the North Atlantic Temperate province (from 8 to $18^{\circ} \mathrm{C}$ ).

In the late sixties and the seventies, other methods for quantitative paleotemperature analysis of planktonic foraminifers were published (Berger, 1968; Lynts and Judd, 1971; Imbrie and Kipp, 1971; Hecht, 1973a, b; Kipp, 1976). Using the last method (Kipp, 1976), very important reconstructions were made (Cline and Hays, 1976; CLIMAP, $1976,1981)$, which are very similar to our reconstructions.

Our method was improved in the course of 15 years of research. Its present variant is used for the entire temperature interval of the Atlantic Ocean: from $2-3^{\circ} \mathrm{C}$ to $27-28^{\circ} \mathrm{C}$.

Based on more than 300 samples of surface sediment, micropaleontologic analysis of sediment from the Atlantic, mainly from its northern part, resulted in distribution maps for all planktonic foraminiferal species (Barash, 1970, 1971, for the North Atlantic, and our unpublished data for other parts of the Atlantic Ocean). Only samples of well-preserved foraminiferal complexes were used to relate the mapped distributions to temperature.

Because total "annual" thanatocoenoses are accumulated in the sediment, we analyzed the connection between the distribution of each species and the annual temperature, not the temperature of separate seasons. Sea-surface temperatures were read from Schott's maps (1944).

Our maps for the species distributions allowed us to plot a "temperature sequence", an arrangement of species distribution from coldwater to warm-water preference. First, the sequence reveals the regions that contain maximum concentrations of each species in the sediment. When the maxima of the species occur in regions of similar temperatures, the general visual trend is considered (whether the gradients of the concentration decrease with the increase or decrease of the temperature). When maxima and trend coincide, the temperature limits of the species distributions are examined. The derived "temperature line" of the species is subdivided into climatic groups according to the position of the regions that have the maximal concentration of each species in various climatic zones (Barash and Blyum, 1974). The species can be grouped as follows:

1) The Subpolar Group consists of only left-coiling Globoquadrina pachyderma.

2) The Temperate Group includes Globigerina quinqueloba, G. bulloides, Globigerinita bradyi, right-coiling Globoquadrina pachyderma, and Globigerinita glutinata.

3) The Subtropical Group includes Globorotalia inflata, G. scitu$l a$, right-coiling $G$. truncatulinoides, $G$. hirsuta, left-coiling $G$. truncatulinoides, G. crassaformis, Globigerina falconensis, G. calida, and G. humilis;

4) The Tropical Group consists of Globorotalia tumida, Orbulina universa, Globigerinoides ruber, G. conglobatus, Globoquadrina dutertrei, and Globigerina rubescens + Globigerinoides tenellus.

5) The Equatorial Group includes Globigerinoides sacculifer, Globigerinella aequilateralis, Globorotalia menardii, Pulleniatina obliquiloculata, Candeina nitida, Sphaeroidinella dehiscens, and Globigerina digitata.

Because most species spread into the neighboring climatic zones, the thanatocoenoses usually consist of specimens of several species groups. The content of each group indicates the water temperature and varies regularly with its changes (Fig. 1). The ratios between various groups allows us to distinguish several types and subtypes of thanatocoenoses that are distributed on the seafloor as sublatitudinal

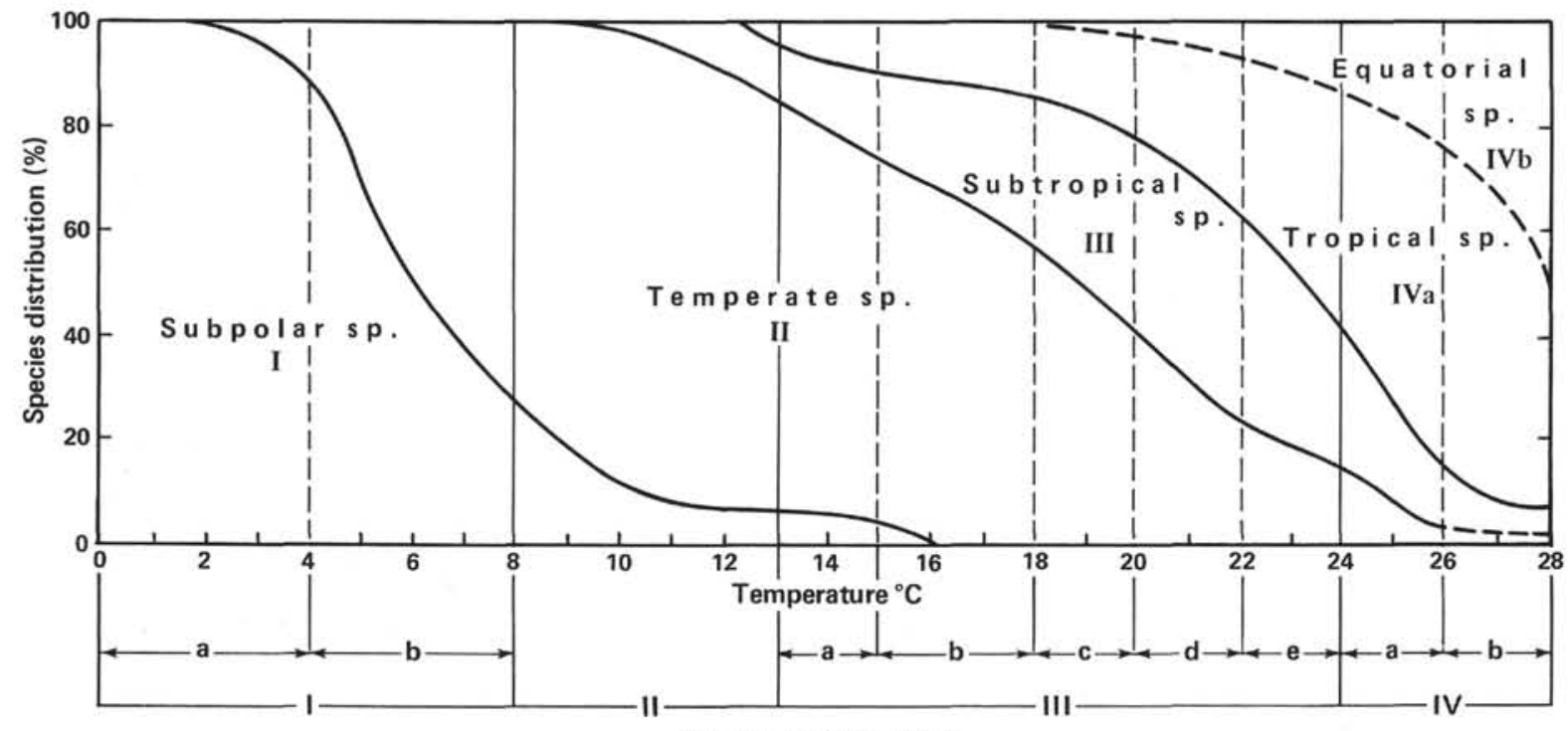

Thanatocoenoses types

Figure 1. Ratio between the climatic groups of planktonic foraminiferal species in the surface sediments of the Atlantic as a function of the annual temperature of the surface water. Thanatocoenoses types: $I=$ polar $(a=$ polar subtype; $b=$ subpolar subtype); II = temperature (Subtypes a-d, see Table 1); III = subtropical (Subtypes a-e); IV = tropical $(a=$ tropical subtype, $\mathrm{b}=$ equatorial subtype). 
strips of $2-3^{\circ} \mathrm{C}$ intervals of the annual temperature (Table 1) (Barash and Blyum, 1975). Besides indicating the ratio between the climatic groups and number of species, tables illustrating thanatocoenoses characteristics also contain information on the dominant species. The concentration of species belonging to one climatic group (Fig. 1) is summed; then the average annual temperature of the surface water during the sediment accumulation is estimated by the key table (Fig. 1 and Table 1).

The species content of climatic groups varies within each thanatocoenosis type. At first, the temperature is defined for each group separately. In the ideal case, all individual temperature estimates for climatic groups should coincide. In reality, they are similar or close. If the deviation of temperatures reaches $2-4^{\circ} \mathrm{C}$, the average temperature is defined. If one group shows sharply different temperature, it is excluded from consideration. Destruction of the normal oceanic structure of thanatocoenosis occurs within the frontal zones or is caused by partial dissolution at great depths. Such samples also allow reconstructions, although such reconstructions require a subjective approach and some intuition based on the experience of the researcher.

When the method is applied for the Atlantic as a whole, average standard error is $\pm 1.5^{\circ} \mathrm{C}$ within $76.5 \%$ level of confidence (Barash, unpublished data). The greatest accuracy is in the Subtropical Zone, the least in the Equatorial Zone. The greater accuracy seems doubtful because thanatocoenoses do not show more precise connections to water mass parameters (in particular, with temperature). These parameters are rather variable, even if the scale is tens of years. Thanatocoenoses, however, because of the low rate of oceanic sedimentation, reflect integral characteristics of the sedimentation for hundreds and thousands of years.

Our method has been used to perform a number of paleoceanologic reconstructions (Barash, 1974, 1981; Barash and Os'kina, 1978; Barash et al., 1980; Barash and Okuneva, 1981). The results closely correspond to the reconstructions done in the CLIMAP Project (CLIMAP, 1976, 1981; Cline and Hays, 1976).

\section{HOLE 516}

\section{Planktonic Foraminiferal Biostratigraphy}

Forty-six samples from the uppermost $11.3 \mathrm{~m}$ at Hole 516 were quantitatively analyzed for their planktonic foraminiferal fauna. We made analyses of successive samples, starting from the mudline downsection, until convincing evidence of the Pliocene/Pleistocene boundary was obtained (Fig. 2).

All samples contain abundant and well-preserved planktonic foraminiferal fauna; concentration of shells larger than $0.1 \mathrm{~mm}$ usually reaches several tens of thousands per $\mathrm{g}$ of dry sediment (Fig. 2). This sandy fraction is almost entirely planktonic foraminiferal tests (96$100 \%$ ). The remainder contains shells of benthic foraminifers, ostracodes and rarely mineral grains. In all, we identified about 50 species of planktonic foraminifers (Appendix A). Each sample contains about 20 to 30 species. We also recognized subspecies and morphologic variations that, when counted, were attributed to their corresponding species. Globigerina rubescens and Globigerinoides tenellus have small tests that are difficult to distinguish; therefore, those counts were combined. Also, other species and specimens were detected that require special, thorough analysis, and, thus, fall beyond the scope of the present work.

Most of the species concerned evolved before the Quaternary. They occur throughout the section and,

Table 1. Correlation between the structure of thanatocoenoses of planktonic foraminifers and water temperature.

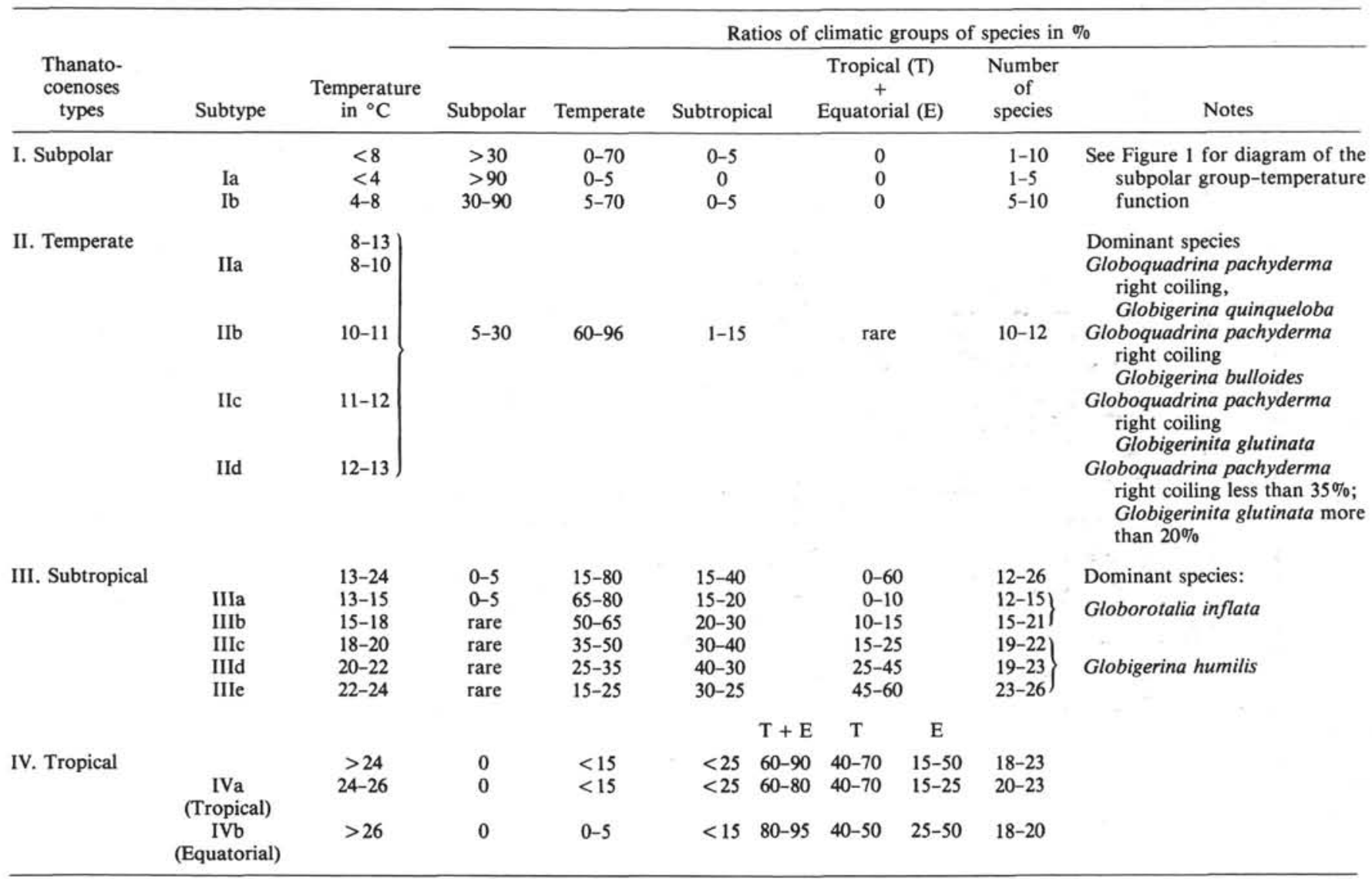




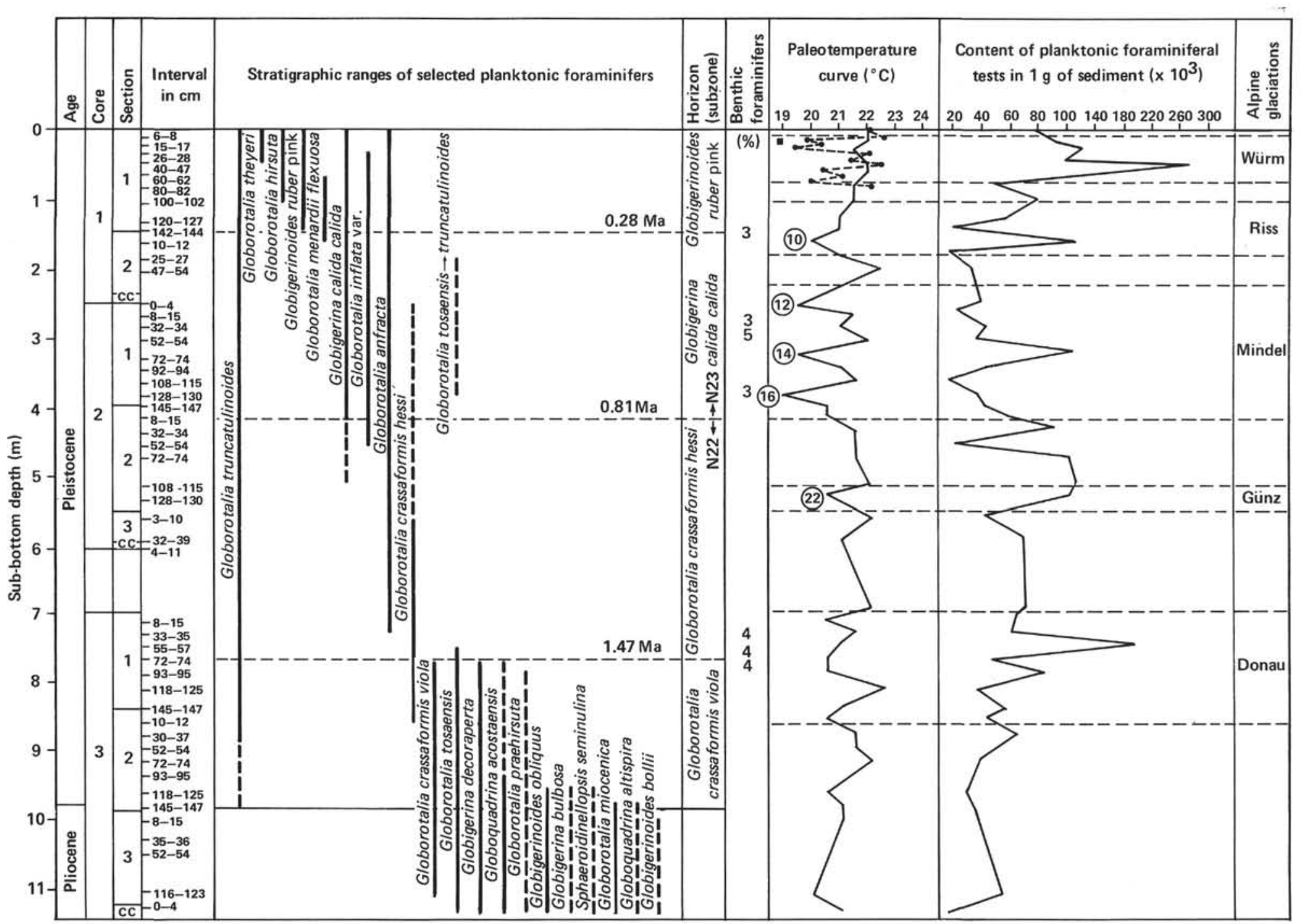

Figure 2. Quaternary biostratigraphy, paleotemperatures, and planktonic foraminiferal number, Hole 516. The figure shows boundaries of Zones N22 and N23, intervals of the elevated concentration of benthic foraminifers, and the preliminary correlation of temperature peaks with oxygen isotope stages (stage numbers are shown by encircled figures) and with Alpine glaciations. The dashed line in the upper segment of the paleotemperature curve is the paleotemperature curve according to Mikhail Lomonosov Core L-878 $\left(28^{\circ} 26.1^{\prime} \mathrm{S}, 33^{\circ} 23.0^{\prime} \mathrm{W}\right)$. The black rectangle on the left is a sample with radiocarbon dating about 23,000 years. 
therefore, cannot be used for its biostratigraphic subdivision. There are, however, species with restricted vertical ranges (in particular, abundant subspecies of Globorotalia crassaformis: viola, hessi, crassaformis, ronda, and oceanica) (Plates 1-3).

Large changes in the composition of foraminiferal fauna occur in Section 516-3-2. One datum level was defined a bit lower, specifically the last appearance datum (LAD) of Globorotalia exilis (Sample 516-3-3, 8-15 $\mathrm{cm}$ ). Higher, the LADs of four Pliocene species (Globoquadrina altispira, Globorotalia miocenica, Globigerinoides bollii, and Pulleniatina primalis) occur in Sample 516-3-2, 145-147 cm. The same sample seemed to reveal the first appearance datum (FAD) of Globorotalia truncatulinoides; one small specimen with distinct keel was identified (Plate 2, Fig. 2). The species was not detected in any sample lower than this section, with the exception of Sample 516-3,CC, which contains several very large and developed specimens. This occurrence in the core catcher can be explained, however, by the mechanical displacement of the younger sediment during the drilling.

Sample 516F-3-2, 118-125 cm contains the LADs of Globigerinoides obliquus, Globigerina apertura, G. bulbosa, and Sphaeroidinellopsis seminulina; it also marks the change in dominant coiling direction of the Globorotalia menardii s.l. complex. Large left-coiling $G$. menardii typical of the Quaternary appear.

In this 30-cm thick interval, therefore, are criteria of the Pliocene/Pleistocene boundary. If the Globorotalia truncatulinoides Zone corresponds to the Quaternary, the Pliocene/Pleistocene boundary may be placed below Sample 516-3-2, 145-147 cm, a depth about $9.8 \mathrm{~m}$ below the seafloor. A number of authors (Vincent et al., 1974) used to draw this boundary not by the initial appearance, but by the abundant occurrence of Globorotalia truncatulinoides in the section, which occurs in Sample $516-3-2,72-74 \mathrm{~cm}$. By that method, the boundary would occur about $9.2 \mathrm{~m}$ below the mudline.

Considering the restricted ranges of species and subspecies, we can subdivide the Quaternary section into four parts. Characteristics of the three lower subdivisions mainly correspond to the definitions of the subzones originally described by Bolli and Premoli Silva (1973) and later by other authors (Rögl, 1974; Krasheninnikov and Pflaumann, 1977; Krasheninnikov, 1977, 1979a, b). Comparison of their thicknesses, however, shows different age restrictions between the Hole 516 and 518 subzones, the subzones detected by Bolli and Premoli Silva (1973), and those of other authors. A general subdivision of the Quaternary, nevertheless, is possible and gives evidence of similar, though not simultaneous, faunal changes in various regions of the world ocean. We define these subdivisions as faunal intervals.

1) The Globorotalia crassaformis viola interval embraces the lower Quaternary section up to Sample 516$3-1,72-74 \mathrm{~cm}$ (9.8 to $7.6 \mathrm{~m}$ sub-bottom). Globorotalia truncatulinoides co-occurs here with $G$. crassaformis viola. Globoquadrina acostaensis and Globigerina de- coraperta persist throughout the horizon. In the uppermost samples, these Pliocene species are small, suppressed specimens. Globorotalia tosaensis is present in all samples. In the upper half of the interval (above Sample 516-3-2, 10-12 cm), G. crassaformis hessi occurs.

2) Globorotalia crassaformis hessi interval starts from the level of the $G$. crassaformis viola disappearance and continues to the level at which typical Globigerina calida calida appears (Sample 516-2-2, 8-15 cm; 7.6-4.2 $\mathrm{m}$ sub-bottom). Well-developed specimens of index subspecies are typical of these complexes, especially in the lower half of the interval. Sample 516-3-1, 33-35 $\mathrm{cm}$, marks the first occurrence of Globorotalia anfrac$t a$, which is traced upwards throughout the section. $G$. bermudezi occurs only in the upper half of this interval. Several uppermost samples contain specimens resembling Globigerina calida calida. Typical Globorotalia tosaensis occur only in the two lower samples from this interval.

3) Globigerina calida calida interval was detected between the level marking the appearance of developed specimens of the index subspecies and the FAD of pink specimens of Globigerinoides ruber and Globigerina rubescens (4.2-1.44 m sub-bottom). Globorotalia crassaformis hessi disappears in this interval, which is marked by specimens of $G$. truncatulinoides with keels so poorly developed that sometimes they cannot be distinguished at all. These specimens seem to be the last transitional forms between $G$. truncatulinoides and $G$. tosaensis. $G$. inflata var., which differs from the typical form by its more sharp angle-like peripheral edge, occurs throughout the interval.

4) Globigerinoides ruber (pink) interval contains, besides the index form, specimens of pink Globigerina rubescens. The interval brackets the upper $1.44 \mathrm{~m}$ of the section. At $100 \mathrm{~cm}$ sub-bottom (Sample 516-1-1, 100$102 \mathrm{~cm}$ ), the first large specimens of the right-coiling Globorotalia hirsuta occur. In the middle of this interval, specimens of $G$. menardii flexuosa (Sample 516-1$1,60-62 \mathrm{~cm}$ ) and of $G$. inflata var. (Sample 516-1-1, 26-28 cm) disappear. Sample 516-1-1, 40-47 cm, marks the appearance of $G$. theyeri.

Hole 516 was drilled near the crest of the Rise. The Pleistocene section shows no signs of redeposited sediment, hiatuses in sedimentation, or dissolution of shells. Consequently, it is possible to suppose that sedimentation proceeded at relatively regular rates. In the subtropical and temperate latitudes of the Atlantic, $G$. truncatulinoides appeared a bit earlier than the base of the Olduvai Event, about 1.9 Ma (Berggren et al., 1980). On the basis of these suppositions and interpolation, the upper boundary for G. crassaformis viola interval is traced back to $1.47 \mathrm{Ma}$, the G. crassaformis hessi/Globigerina calida calida boundary is dated as $0.81 \mathrm{Ma}$, and the age of the lower boundary of the Globigerinoides ruber (pink) interval is determined as $0.28 \mathrm{Ma}$. The age of the lower boundary of Globigerina calida calida interval corresponds to the age of the G. calida calida 
Subzone (Berggren and Van Couvering, 1974). This fact allows us to identify this level as the boundary between Zones N22 and N23 (Blow, 1969).

\section{Paleotemperatures}

Planktonic foraminiferal complexes in the analyzed section of Hole 516 contain almost all present species typical of the Atlantic, and the lower Pleistocene (Globorotalia crassaformis viola Zone) contains several Pliocene species, usually present as rare specimens. This dominance of modern forms allows us to use the micropaleontologic method described above to reconstruct the average annual paleotemperatures of the surface water. Ratio of species of various climatic groups throughout the section corresponds to IIIc-IIIe subtypes of the subtropical thanatocoenosis. The dominant species are Globigerina rubescens + Globigerinoides tenellus (15$33 \%$ ), Globigerinoides ruber (up to $20 \%$ ), and Globigerinita glutinata (10-32\%). Globorotalia inflata, G. scitula, Globigerina quinqueloba, and G. humilis reach 10$12 \%$ each in some samples. Concentrations of other species range between 1 and $12 \%$.

The paleotemperature curve ranges from 19 to $22.5^{\circ} \mathrm{C}$, an annual temperature fluctuation of $3.5^{\circ} \mathrm{C}$ (Fig. 2). Many warm-water and cold-water peaks on our curve are based on single samples; their total number is lower than that established on the detailed oxygen isotope curves. Successive comparison of these peaks with the oxygen isotopic stages, therefore, does not seem to be expedient. The extreme cold-water peak at $380 \mathrm{~cm}$ (Sample 516-2-1, 128-130 cm) may correspond to Oxygen Isotopic Stage 16, identified by maximum values of $\delta^{18} \mathrm{O}$ (Shackleton and Opdyke, 1973; Van Donk, 1976). This supposition is supported by the position of the peak slightly above the lower boundary of Globigerina calida calida interval.

Interpretation of the paleotemperature curve based on 43 samples suggests that the average annual temperature of the surface water at Site 516 was $21.2^{\circ} \mathrm{C}$ throughout the Quaternary. The Quaternary boundary corresponds to the interval with $21.0^{\circ} \mathrm{C}$; the sample cored above this interval revealed weak cold peak $\left(20.5^{\circ} \mathrm{C}\right)$. The average temperature during the accumulation of the Globorotalia crassaformis viola interval was $21.2^{\circ} \mathrm{C}$ (9 samples), with weak fluctuations (about $\left.1.5^{\circ} \mathrm{C}\right)$. The same average temperature $\left(21.2^{\circ} \mathrm{C}\right)$ was found for the interval of $G$. crassaformis hessi (11 samples), with temperature fluctuations no more than $1.5^{\circ} \mathrm{C}$.

Temperature decreases relatively sharply from 21.5 to $19^{\circ} \mathrm{C}$ at the base of Globigerina calida calida interval. The average temperature during the accumulation of this interval was minimal throughout the Quaternary (according to 15 samples). Its temperature was $20.8^{\circ} \mathrm{C}$ with amplitude of $3.5^{\circ} \mathrm{C}$ and with temperature fluctuations of about $3^{\circ} \mathrm{C}$ (i.e., from Sample 516-1,CC to Sample $516-1-2,197-204 \mathrm{~cm}$ ). There is a trend to a gradual increase in medial temperature (between the neighboring opposite peaks) throughout this horizon from about 20.5 to $21.5^{\circ} \mathrm{C}$.
The average temperature during the accumulation of the interval of Globigerinoides ruber (pink) was $21.7^{\circ} \mathrm{C}$, and our reconstruction suggests a gradual increase from 21 to $22^{\circ} \mathrm{C}$ during that time span. The absence of temperature fluctuations in this interval is probably explained by the mixing of the soft uppermost sediment during the coring process, which would integrate planktonic foraminiferal complexes of contrasting temperatures. Analysis of the cores obtained by short gravity coring tubes in this region revealed clear temperature fluctuations in the late Pleistocene-Holocene. Core L-878 (from a cruise of the Mikhail Lomonosov; $28^{\circ} 26.1^{\prime} \mathrm{S}$, $33^{\circ} 23.0^{\prime} \mathrm{W}$ ) shows temperature fluctuations starting from the interstadial of the last glaciation (Oxygen Isotopic Stage 3), continuing to the last stadial (Stage 2) and further to the Holocene, when it reached $2.5-3.0^{\circ} \mathrm{C}$ (Barash and Os'kina, 1979). The horizon of the last glaciation stadial (Stage 2) in this core dated by $\mathrm{C}^{14}$-method was recovered at the depth of 15 to $50 \mathrm{~cm}$. The paleotemperature curve for Core L-878 is plotted for comparison; it is the dashed line near the upper part of the curve for cores from Site 516 (Fig. 2). The restricted vertical ranges of some planktonic foraminiferal species suggests insignificant mixing of sediments at Site 516 .

A very important regularity can be inferred from the correlation between LADs of species and the paleotemperature curve. Their disappearance corresponds to the periods of cooling, either to peaks of cooling or to transition periods from a warm-water stage to a coldwater one. In all cases, they disappear when the temperature is less than the average temperature for the Quaternary $\left(21.2^{\circ} \mathrm{C}\right.$ in Hole 516$)$.

Occurrence of species was recorded for both the coldwater and warm-water periods. The FAD of Globorotalia truncatulinoides was recorded in the sample with temperature $21^{\circ} \mathrm{C}$, which is close to the average temperature during the Quaternary. The common appearance of this species is synchronous with warm-water periods $\left(22^{\circ} \mathrm{C}\right)$. Such species variants as Globorotalia crassaformis hessi and G. anfracta appear during the coldwater periods, while Globorotalia inflata var. and Globigerina calida calida appear during the warm-water periods. Data collected from Hole 516 do not permit a conclusion about which species and subspecies appeared within the upper mixed horizon, because there is no good information about the temperature fluctuations during its accumulation.

It is unlikely that $1-2^{\circ} \mathrm{C}$ fluctuations of the annual temperature of the surface water would cause extinction of some species and create conditions for the evolutionary appearance of the others. The region of Site 516 remained within the subtropical gyre of the South Atlantic during the entire period under study. Temperature fluctuations in such areas are minimal (Barash and Okuneva, 1981; CLIMAP Project Members, 1976). Consequently, the relatively small temperature fluctuations established at Site 516 reflect more significant temperature variations and changes in hydrologic structure occurring in other regions of the Atlantic and in the world 
ocean as a whole. Such global changes could have affected the ecological and evolutionary appearance and extinction of planktonic foraminiferal species.

\section{Content of Planktonic and Benthic Foraminiferal Tests in Sediment}

The relatively shallow depth at Site $516(1313 \mathrm{~m})$ near the crest of the Rio Grande Rise accounts for high content of planktonic foraminiferal tests in the sediment (no less than 20,000 specimens per $\mathrm{g}$ of dry sediment; all data are for tests larger than $0.1 \mathrm{~mm}$ ). The foraminiferal number is $20,000-80,000$ per $\mathrm{g}$ in the majority of samples; sometimes, it exceeds 100,000 , and it reaches a maximum of 270,000 in Sample 516-1-1, 60-62 cm (Fig. 2). This sample and others with high concentration of tests (Samples 516-1-2, 10-12 cm; 516-2-1, 72-74 cm; $516-2-2,32-34 \mathrm{~cm} ; 516-3-1,55-57 \mathrm{~cm}$ ) have the same ratio of species as neighboring samples. Some of them have slightly elevated concentrations of small-test species, such as Globigerinita glutinata, Globigerina rubescens, and Globigerinoides tenellus. There is no evidence of any changes in regular sedimentation.

Visual comparison of the paleotemperature and test concentration curves does not immediately reveal their uniform correlation. Nevertheless, peaks of high concentration of tests correspond more often to cold-water periods. In these cases, it is possible to suppose reduction of foraminiferal test sizes and reduction of coccolith inflow in the sediment.

Concentration of benthic foraminiferal tests in the majority of samples is $0-2 \%$ of the total foraminiferal fauna. Figure 2 shows four levels, with concentrations up to $3-5 \%$ (about $160 \mathrm{~cm}, 280-310 \mathrm{~cm}, 380 \mathrm{~cm}$, and $720-780 \mathrm{~cm}$ ). Three of these levels correspond or are close to the boundaries of the faunal intervals defined by restricted vertical ranges of some planktonic foraminiferal species and subspecies. Such coincidence of independent features supports the hypothesis that the detected boundaries mark periods of significant changes in the oceanic environment.

Increase in the number of benthic foraminifers could be attributed to the changes in the bottom circulation. Site 516 is located within the Upper Circumpolar Water, approximately $200 \mathrm{~m}$ below the Antarctic Intermediate Water (Barker et al., 1981). Their basic properties (temperature, salinity, oxygen concentration) differ greatly. Fluctuation of the boundaries between these water masses at Site 516 could have affected the number of benthic foraminifers and their composition. Increase in the number of benthic foraminifers could also be connected with increases in organic material inflow to the bottom sediment. Finally, if the productivity of benthic foraminifers was constant, the increase in the relative concentration of their tests in the total foraminiferal complex could be a result of the decrease in the productivity of planktonic foraminifers. These problems, however, are the subject of a special study of benthic foraminifers (Tjalsma, this volume).

\section{HOLE 518}

\section{Planktonic Foraminiferal Biostratigraphy}

The quantitative analysis of planktonic foraminifers was performed in 80 samples from the uppermost 16.7 $\mathrm{m}$ of the cores at Hole 518 (Fig. 3). The mean interval between samples is $20 \mathrm{~cm}$. Qualitative investigation of the fauna was made slightly lower, down to $17 \mathrm{~m}$ sub-bottom. Analyzed samples show abundant fauna of planktonic foraminifers, predominantly well preserved. The sand fraction of the sediment (larger than $0.1 \mathrm{~mm}$ ) usually comprises $99 \%$ of their tests. The remainder of the coarse fraction contains tests of benthic foraminifers, ostracodes, and sometimes other components. Altogether, 50 species of present and extinct species of planktonic foraminifers were recovered (Appendix B). Each sample has 23-35 species.

The first evolutionary appearance of Globorotalia truncatulinoides is recorded at about $15.9 \mathrm{~m}$ depth (Sample $518-5-2,23-30 \mathrm{~cm}$ is redeposited sediment; Sample $518-5-1,133-135 \mathrm{~cm}$ is normal sediment). This level also exposes a sharp change (upward in the section) in the coiling direction of $G$. menardii complex from right coiling to left coiling $(518-5-2,23-67 \mathrm{~cm})$. Sample 518-5-2, 85-87 cm shows the LAD of Globigerinoides bollii. Large, well-developed specimens constitute the $1.9 \%$ concentration of Globoquadrina acostaensis in this sample. Above Sample 518-5-1, 133-135 cm only small and rare specimens of this species are found. Similar changes are observed in Globigerinoides obliquus, Globorotalia miocenica, and Sphaeroidinellopsis seminulina. Samples 518-5-2, 5-7 cm; 518-5-2, 23-30 $\mathrm{cm}$; and 518-5-2, 65-67 cm (15.5-16.3 m sub-bottom) contain well-sorted foraminiferal sand, which was certainly redeposited, and a number of Pliocene species. The Pliocene/Pleistocene boundary can be placed at a depth of about $16 \mathrm{~m}$ sub-bottom in a layer of the redeposited foraminiferal sand.

The Quaternary deposits in Hole 518 can be subdivided into the same faunal intervals as in Hole 516. From bottom to top, these are:

1) Globorotalia crassaformis viola interval brackets the lower Quaternary section (16-10.75 m) up to Sample 518-4-1, 87-89 cm, which shows the last occurrence of index subspecies. This interval is detected by coincidence of $G$. crassaformis viola and $G$. truncatulinoides and characterized by the continuous occurrence of $G$. tosaensis, and, in its lower portion, successive disappearance of some Pliocene species. The latter are represented in lower Pleistocene sections by rare, usually poorly developed small specimens. Sample 518-5-1, 73$75 \mathrm{~cm}$ contains the LADs of Globigerina nepenthes and G. bulbosa; Sample 518-5-1, 27-34 cm, the LAD of Globoquadrina conglomerata; Sample 518-5-1, 10-12 $\mathrm{cm}$, the LADs of G. altispira, Globorotalia miocenica, and Sphaeroidinellopsis seminulina; Sample 518-4,CC, 5-11 cm, the LADs of Globoquadrina acostaensis and Globorotalia exilis; and Sample 518-4-3, 55-57 cm, the LAD of Globigerina decoraperta. The first section of 


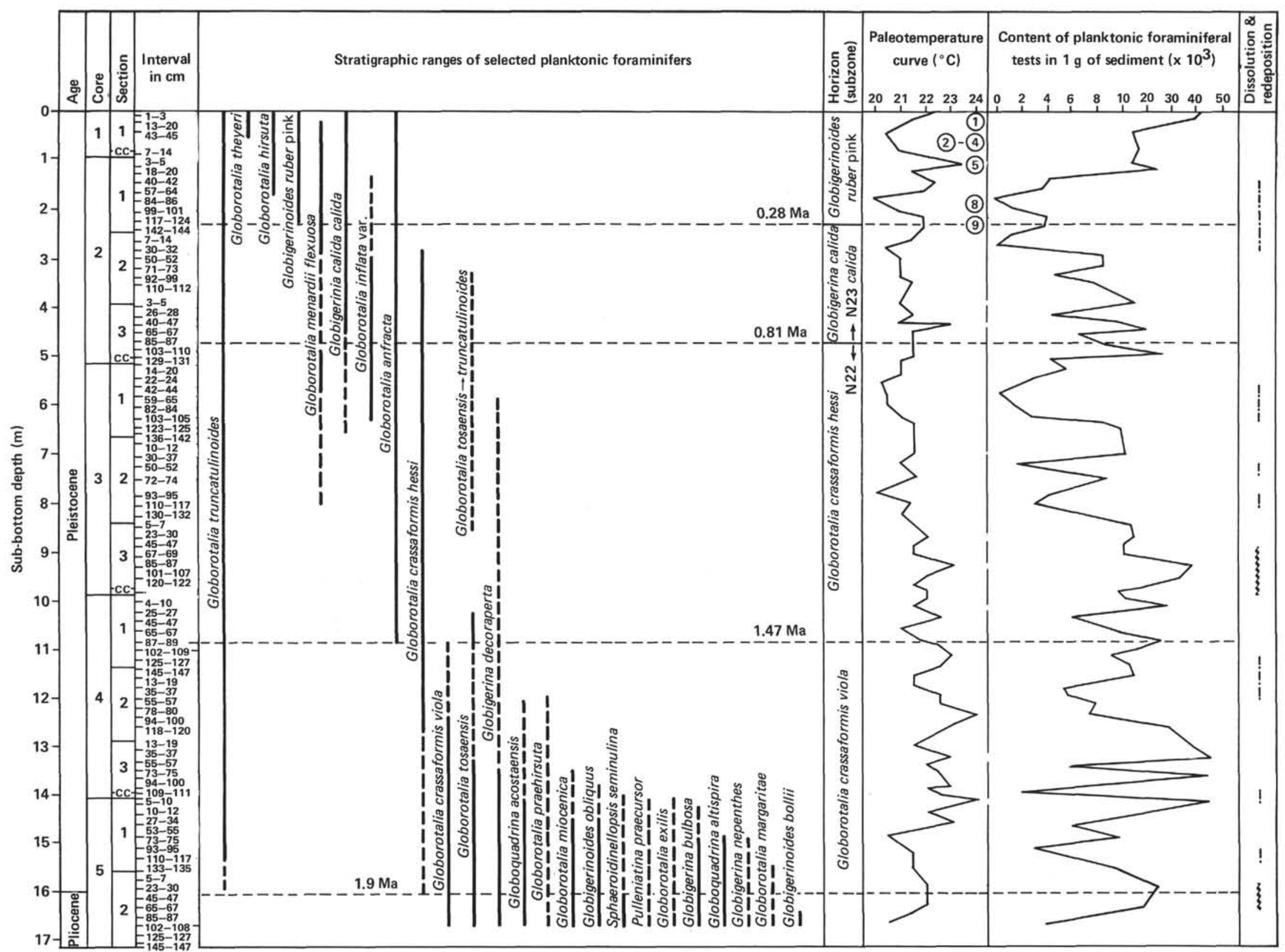

Figure 3. Quaternary biostratigraphy, paleotemperatures, and planktonic foraminiferal num ber, Hole 518. The figure shows boundaries of Zones N22 and N23, preliminary correlation between temperature peaks and oxygen isotope stages (stage numbers are shown by figures in circles), layers with signs of dissolution (dash-dot line in the right border), and layers with redeposited sediment (wavy line in the right border). 
the fifth core, thus, shows massive disappearance of a number of Pliocene species at about $14 \mathrm{~m}$ sub-bottom. Some Pliocene species, absent in the corresponding section in Hole 516, are recovered in the lower section of the interval. These tests are perhaps redeposited from eroded Pliocene outcrops located upslope.

2) Globorotalia crassaformis hessi interval is detected between 10.7 and $4.65 \mathrm{~m}$ sub-bottom, the LAD of G. crassaformis viola and the FAD of typical Globigerina calida calida specimens (Sample 518-2-3, 85-87 $\mathrm{cm})$. Large and well-developed Globorotalia crassaformis hessi specimens occur throughout, and $G$. anfracta appears at the base of the interval (Sample 518-4-1, $87-99 \mathrm{~cm}$ ), slightly beneath the level of disappearance of typical G. tosaensis (Sample 518-3-2, 130-132 cm). A layer of redeposited, well-sorted foraminiferal sand, containing the Pliocene species G. exilis, G. pertenuis, Globoquadrina altispira, and Sphaeroidinellopsis seminulina occurs within the interval (Samples 518-3-3, 45-47 $\mathrm{cm}$ to $518-3-3,120-122 \mathrm{~cm}$ ).

3) The Globigerina calida calida interval occurs between 4.65 and $2.25 \mathrm{~m}$ sub-bottom and is defined by the FADs of distinct specimens of index subspecies and of pink specimens of Globigerinoides ruber and Globigerina rubescens. Globorotalia inflata var. with a sharp periphery occurs almost throughout the interval. In the upper portion of the interval (at about $3 \mathrm{~m}$ sub-bottom) are the LADs of Globorotalia crassaformis hessi and $G$. truncatulinoides with either a poorly shaped keel or no keel. These forms are possibly transitional between this species and $G$. tosaensis.

4) The Globigerinoides ruber (pink) interval is identified by the occurrence of this form and of pink Globigerina rubescens. Above the base of the interval (Sample $518-2-1,56-64 \mathrm{~cm}$ ) is the FAD of large, well-developed Globorotalia hirsuta (Plate 3, Figs. 8-10). The upper sections of the interval (Samples 518-1-1, 43-45 cm and 518-1-1, 13-20 cm) show single specimens of Globorotalia theyeri (Plate 3, Fig. 11). Globorotalia menardii (tumida) flexuosa (Plate 3, Fig. 1), which is sometimes recorded below this level, occurs in this interval up to Sample 518-1-1, 13-20 cm.

\section{Paleotemperatures}

The assemblages of planktonic foraminifers in the analyzed portion of Hole 518 consist of species from the Temperate, Subtropical, Tropical, and Equatorial-Tropical groups. Their quantititative ratios fluctuate within the subtropical thanatocoenosis type from the IIId to the IIIe subtypes. Concentrations of $10 \%$ and more are registered for Globigerinita glutinata, Globigerinoides ruber, Globigerina rubescens + Globigerinoides tenellus, Globoquadrina pachyderma (right coiling), Globorotalia inflata, and Globigerina humilis. Because the last three species are relatively resistant to dissolution, sharp increases in their concentrations mark zones of partial dissolution.

Reconstructed foraminifer-based paleotemperatures of the surface water in the region of Site 518 reveal minimal temperatures of $20.5^{\circ} \mathrm{C}$ for well-preserved samples (Fig. 3). Samples with temperatures of $20^{\circ} \mathrm{C}$ all contain foraminiferal complexes affected by partial dissolution; the derived temperature is thus slightly lowered because the relatively abundant cold-water species, right-coiling Globoquadrina pachyderma and Globorotalia inflata, are more resistant to dissolution. Maximal temperatures reach $24^{\circ} \mathrm{C}$. The temperature fluctuation of the surface water at Site 518 is $3.5^{\circ} \mathrm{C}$, if poorly preserved samples are discarded. The average temperature throughout the Quaternary at Site 518 is $21.7^{\circ} \mathrm{C}(68$ samples, excluding samples from redeposited sediment layers).

The plotted paleotemperature curve of the Quaternary can be subdivided into $39-40$ alternating cold-water and warm-water intervals of various duration and intensity. The same number of intervals are detected on oxygen isotope curves, in particular Core V16-205 from the Atlantic (Van Donk, 1976). We did not try to correlate the Site 518 paleotemperature intervals with oxygen isotopic stages. Because many peaks on the curve are defined by only one sample and because those extremes are detected somewhat casually as a result of the random sampling, some stages might have been omitted and, in others, the paleotemperatures might not correspond to the real extreme values. Besides, some samples from Site 518 have features of partial dissolution of planktonic foraminifers; therefore, aberrant temperatures are possible. Disregarding the samples that have distinct features of dissolution and redeposition, the highest average annual temperature of $22.3^{\circ} \mathrm{C}(21 \mathrm{sam}$ ples) for the Quaternary was during the accumulation of the Globorotalia crassaformis viola interval. At the very end of the Pliocene (Sample 518-5-2, 102-108 cm) and at the beginning of the Pleistocene (Sample 518-5-1, $73-75 \mathrm{~cm}$ ), the minimal temperature was $20.5^{\circ} \mathrm{C}$. These temperature intervals are separated by a warmer-water stage corresponding to the Pliocene/Pleistocene boundary. Such a low temperature is unique to the Site 518 Pleistocene samples with well-preserved foraminiferal assemblages. Only one sample (518-1-1, 43-45 cm) is an exception, and it belongs to the last cold-water interval. A maximum temperature of $24^{\circ} \mathrm{C}$ is recorded during the accumulation of Globorotalia crassaformis viola interval (Samples 518-5-1, 10-12 cm and 518-4-2, 94-100 $\mathrm{cm}$ ). This maximum was not approached again above this sub-bottom level, with the exception of one sample in the penultimate warm-water interval (Sample 5182-1, 3-5 cm).

Relationships between the temperature fluctuations and LADs of some species have been found. Sample 518-5-1, 73-75 cm, a cold-water assemblage, marks the LADs of Globoquadrina altispira and Globigerina nepenthes. The subsequent temperature increase and fluctuations in samples from Section 518-5-1 correspond to the intervals with LADs of more Pliocene species and to the sharp fluctuations in foraminiferal test contents in sediment. The uppermost part of the interval shows a decreasing-temperature trend.

Reconstructed temperatures are relatively stable for the Globorotalia crassaformis hessi interval and deviate weakly from the average of $21.3^{\circ} \mathrm{C}$ ( 23 samples). Apparently there was little contrast between this and the Glo- 
bigerina calida calida interval characterized by an average temperature of $21.4^{\circ} \mathrm{C}$ (13 samples) and minor fluctuations.

The lower boundary of the Globigerinoides ruber pink interval is within the underlying warm-water interval attributed to the Oxygen Isotopic Stage 9. The age of this boundary $(0.277 \mathrm{~m} . \mathrm{y}$.) is probably reduced because the uppermost sediment is absent, but it is close to the age of the boundary between Stages 9 and 8 (Morley and Hays, 1981). The average temperature for Globigerinoides ruber pink interval is $21.6^{\circ} \mathrm{C}$ (11 samples). Although the mean is close to those of the previous two intervals, this period is marked by a general trend of increasing temperature and higher amplitude fluctuations. The cold-water peaks at 1.25 and $1.75 \mathrm{~m}$ sub-bottom seem to correspond to Stages 6 and 8, respectively. Temperature decreases from $23.5^{\circ} \mathrm{C}$ to $20.5^{\circ} \mathrm{C}$ within the interval from Samples 518-2-1, 3-5 cm to 518-1-1, 43-45 cm. The first sample can be tentatively matched with Stage 5 of oxygen isotope scale, the warmest-water stage of the last stages. This supposition is supported by the age of the peak, about $125,000 \mathrm{yr}$., established by the interpolation of the boundary of Globigerinoides ruber pink (277,000 yr. ago) located at the depth $2.25 \mathrm{~m}$. In Hole 518 , above Stage 5, the curve shows a continuous cool interval with a minimal temperature of $20.5^{\circ} \mathrm{C}$. The cold-water interval between Samples 518-1-1, 13-20 cm and $518-1, \mathrm{CC}, 7-14 \mathrm{~cm}(0.15-0.75 \mathrm{~m}$ sub-bottom) corresponds to Stages 2-4 (indistinguishable because of poor sampling). This correlation is supported by the position of the level of disappearance of Globorotalia menardii (tumida) flexuosa, which by our data reached its evolutionary extinction in the Atlantic about 25,000 years ago. Sample 518-1-1, 43-45 cm contains several specimens of this species, but Sample 518-1-1, 13-20 cm contains only one poorly flexuose specimen. The reconstructed temperature for the uppermost sample is $22.5^{\circ} \mathrm{C}$, a little higher than the present annual temperature of $21-22^{\circ} \mathrm{C}$ for this region, may represent the Holocene climatic optimum (Stage 1).

\section{Processes of Redeposition and Dissolution}

To reveal specific features of the sedimentation and bottom circulation at Site 518, located on the lower slope of the Rio Grande Rise at a depth of about $4 \mathrm{~km}$, we also analyzed the composition of planktonic foraminiferal assemblages, computed the number of tests per $\mathrm{g}$ of dry sediment and the ratio of planktonic and benthic foraminifers, examined the preservation of the shells, and investigated any peculiar properties of the sediment.

Samples at two stratigraphic layers are well-sorted foraminifers. Besides Pleistocene species, rare specimens of Pliocene species occur. For instance, Sample 518-3-3, $85-87 \mathrm{~cm}$ contains Globoquadrina altispira, Globorotalia exilis, and Sphaeroidinellopsis seminulina, as well as Globorotalia crassaformis viola, which occurs continuously in samples lower in the Quaternary. The latter species is also present in Sample 518-3-3, 101-107 cm. Sample 518-3-3, 120-122 cm contains specimens of Globorotalia pertenuis and Globoquadrina altispira. Above this level of obvious redeposition are intervals of inflow of sediment, perhaps from neighboring Pliocene outcrops. Sample 518-3-3, 45-47 cm, contains a nonsorted, redeposited foraminiferal ooze with rare specimens of Globorotalia exilis, elevated concentrations, compared to the neighboring horizons, of large-test species (Globorotalia inflata, G. crassaformis, Globigerinoides ruber, G. conglobatus, Orbulina universa), and diminished concentrations of small-test species (Globigerina quinqueloba, absent; Globigerinita glutinata; G. iota; Globorotalia scitula; Globigerina rubescens + Globigerinoides tenellus) (Appendix B). Thus, the part of the Quaternary from Sample 518-3-3, 45-47 cm to Sample 518-3-3, $120-122 \mathrm{~cm}(8.75-9.52 \mathrm{~m}$ sub-bottom) is composed of redeposited and sorted sediment. This interval does not seem to be a continuous interval of erosion and redeposition; at least one horizon within this range shows no evidence of redeposition (Sample 518-3-3, 67-69 cm). Our paleotemperature analysis showed $21.5-22.0^{\circ} \mathrm{C}$ for this redeposited interval, which is approximately the average temperature for the lower half of Pleistocene (Matuyama Epoch). Temperature is a little higher, $23^{\circ} \mathrm{C}$, only in Sample 518-3-3, 85-87 cm; this can be explained by bottom current winnowing from the assemblages of the small-tests and of the relatively cold-water species Globigerina quinqueloba and Globigerinita glutinata. The concentration of G. glutinata in the layers above and below this interval is $15-20 \%$, but in Sample 518-3$3,85-87 \mathrm{~cm}$, it is $7.8 \%$.

The other redeposited interval occurs in the lower part of the analyzed section. Samples between 15.7 and $16.3 \mathrm{~m}$ sub-bottom are well-sorted foraminiferal sand. They show a decrease of the same small-shell species and an increase of the large-shell species equivalent to that in the upper redeposited horizon; however, the species composition of the assemblages does not reflect the redeposition process. The presence of older material, however, seems to be indicated by increases in the concentrations of Pliocene large-shell species (Sample 518-5-2, 23-30 cm) Globorotalia tosaensis, Globoquadrina altispira, and Globigerinoides obliquus. Both redeposited intervals have a rather high concentration of foraminiferal shells ( 20,000 to 40,000 per $g$ of sediment).

The degree that the bottom water is corrosive to $\mathrm{CaCO}_{3}$ is characterized by the following signs in some horizons at Site 518: (1) the assemblages contain numerous fragments of tests; (2) the concentration of tests decreases to several thousands, and sometimes to several hundreds, of specimens per $\mathrm{g}$ dry sediment; (3) the relative concentrations of species that are resistant to dissolution increase; (4) the concentrations of benthic foraminiferal shells increase up to 6-8\%. Several layers in the analyzed section of Site 518 have different combinations of these signs, which indicates partial dissolution of the foraminiferal assemblages. The interval 1.4-2.75 m sub-bottom is marked by poor or average preservation of tests; their concentrations do not exceed 4,000-5,000 per $\mathrm{g}$ of sediment, and the concentrations both of benthic species and of species that are, according to Berger (1970), dissolution resistant (Globoquadrina pachyderma right coiling, Globorotalia inflata, 
Globigerinita glutinata) increase. In Samples 518-2-1, $84-86 \mathrm{~cm}$ and $518-2-2,30-32 \mathrm{~cm}$, dissolution features are extremely strong. Preservation is bad, and foraminiferal number is $280-700$ tests per $\mathrm{g}$ of sediment. The concentrations of right-coiling Globoquadrina pachyderma are 17 and 22\%; of Globigerina humilis, 32 and $15 \%$; and of benthic foraminifers, 8.0 and $6.2 \%$, respectively.

Other horizons with similar features of partial dissolution of foraminiferal complexes are detected within the intervals between Samples 518-3-1, 42-44 cm and 518-3-1, 103-105 cm; Samples 518-3-2, 50-52 cm and 518-3-2 110-117 cm; Samples 518-4-1, 125-127 $\mathrm{cm}$ and 518-4-2, 78-80 cm; and Samples 518-4-3, 94-100 cm and 518-5-1, 93-95 cm. Degree of dissolution of these complexes varies from sample to sample (see Appendix B and Fig. 3). Below the 10-m level, traces of dissolution are indistinct; the foraminiferal number does not drop below 2,000 per $\mathrm{g}$ of sediment; the concentration of dissolution-resistant species does not increase.

Dissolution of the tests could be attributed to the increases in the level of AABW introduced here by the Weddell Sea Deep Water (Barker et al., 1981). Comparison of the foraminiferal number curve and micropaleontologic paleotemperature curve reveals general coincidence of levels with minimal concentration of shells and intervals of cooling. Although the selective dissolution of complexes could stimulate the temperature effect due to some higher resistivity of the relatively cold-water species, our data suggest an increase in the northward flow of cold bottom water through the Vema Channel during the cold periods. This process was the most active during the accumulation of the upper part of Hole 518 , Sections 518-3-1, 518-2-2, and 518-2-1.

\section{BIOSTRATIGRAPHY OF THE QUATERNARY DEPOSITS IN THE RIO GRANDE RISE REGION}

The Globorotalia truncatulinoides Zone is subdivided into four faunal intervals corresponding to various evolutionary stages of planktonic foraminifers in this province. According to the zonal scheme of Banner and Blow (1965), the $G$. truncatulinoides Zone, which brackets the uppermost $9.8 \mathrm{~m}$ in Hole 516 and $16 \mathrm{~m}$ in Hole 518 , corresponds to the Quaternary.

The FAD of $G$. truncatulinoides corresponds to the level of the change in the coiling direction of $G$. menardii complex (from right coiling to left coiling). In Hole 516, the LAD level of $G$. exilis extends $10 \mathrm{~cm}$ deeper than the FAD level of $G$. truncatulinoides. The levels of disappearance of Globoquadrina altispira, Globorotalia miocenica, Globigerinoides bollii, and Pulleniatina primalis correspond to the level of the first occurrence of Globorotalia truncatulinoides, while the level of disappearance of Globigerinoides obliquus and Sphaeroidinellopsis seminulina is $20 \mathrm{~cm}$ higher. Berggren and others (1980) determine similar mutual distributions of the majority of these datum levels. Faunal changes marking the Pliocene/Pleistocene boundary occur, therefore, within a $30-\mathrm{cm}$ interval. The base of the Globorotalia truncatuli- noides Zone in Hole 516 is defined by only one specimen of this species; a number of authors (Vincent et al., 1974), however, draw the Pliocene/Pleistocene boundary by the common occurrence of this species, which in this case is $75 \mathrm{~cm}$ higher than its first appearance. At Site 518 , some of the enumerated species and other Pliocene species were recovered stratigraphically higher in the lower Pleistocene deposits, perhaps because of the reworking of Pliocene sediment from upslope.

Three of the four faunal intervals within the Globorotalia truncatulinoides Zone were first detected by Bolli and Premoli Silva (1973) for the division of the Quaternary deposits in the Caribbean Sea. Their scheme was also used for stratigraphy of the Pleistocene sediments in the Madeira Islands, Cape Verde, Sierra Leone Rises, Columbian and Venezuelan Basins, Mid-Atlantic Ridge slopes, and Timor Trench (Rögl, 1974; Krasheninnikov and Pflaumann, 1977; Krasheninnikov, 1977, $1978,1979 a, b)$. Using the names of the subzones proposed by Bolli and Premoli Silva (1973), we have modified their faunal definitions; the stratigraphic ranges, therefore, are different. Nevertheless, the possibility of their identification testifies to similar, though not simultaneous, changes in the composition of the planktonic foraminiferal fauna in various oceanic regions.

Cores from Holes 516 and 518 contained the following subdivisions of Globorotalia truncatulinoides Zone (from lower to upper):

1) The G. crassaformis viola interval in Hole $516 \mathrm{em}$ braces the lower Quaternary section from 9.8 to $7.6 \mathrm{~m}$ sub-bottom, and, in Hole 518, from 16 to $10.7 \mathrm{~m}$ subbottom. The co-occurrence of $G$. truncatulinoides, $G$. crassaformis viola, and $G$. tosaensis marks this interval.

The occurrence and disappearance of $G$. crassaformis hessi is difficult to detect because of the presence of the transitional forms from $G$. crassaformis crassaformis to $G$. crassaformis hessi. In Hole 516, G. crassaformis hessi appears $1.3 \mathrm{~m}$ higher in the section than $G$. truncatulinoides, but in Hole 518 they appear simultaneously. For Hole 518, therefore, we cannot use the original definition proposed by Bolli and Premoli Silva (1973) (from the first appearance of $G$. truncatulinoides to the first appearance of $G$. crassaformis hessi).

In Hole 516, Globoquadrina acostaensis and Globigerina decoraperta are traced throughout the horizon; in the upper part, these Pliocene species are small and poorly developed. In Hole 518, distinct specimens of these two species disappear a little below the upper boundary of the interval; its lower half, however, contains specimens of other Pliocene species (Globigerina nepenthes, G. bulbosa, Globoquadrina conglomerata, Globorotalia miocenica, G. exilis, and Sphaeroidinellopsis seminulina). This phenomenon can be explained at least partially by downslope transport.

2) The Globorotalia crassaformis hessi interval occupies the section from 7.6 to $4.4 \mathrm{~m}$ sub-bottom in Hole 516 and from 10.7 to $4.65 \mathrm{~m}$ sub-bottom in Hole 518. It is bracketed by the LAD level of $G$. crassaformis viola and the first occurrence of developed specimens of Globigerina calida calida. Occurrence of well-developed 
specimens of Globorotalia crassaformis hessi is typical. Appearance of $G$. anfracta and disappearance of "typical" $G$. tosaensis mark the base of the interval.

3) The Globigerina calida calida interval continues from 4.2 to $1.5 \mathrm{~m}$ sub-bottom in Hole 516 and from 4.65 to $2.25 \mathrm{~m}$ sub-bottom in Hole 518 . It is defined as the interval between the first occurrence of developed index subspecies and the first occurrence of pink Globigerinoides ruber and Globigerina rubescens. Globorotalia crassaformis hessi and G. truncatulinoides var. disappear in this interval. The latter has a poorly developed keel or no keel, and is probably the last transitional form between this species and G. tosaensis. Specimens of $G$. inflata var. occur throughout the horizon. These differ from the typical form by their angular periphery.

4) Globigerinoides ruber pink interval is placed above $1.5 \mathrm{~m}$ sub-bottom in Hole 516 and above $2.25 \mathrm{~m}$ subbottom in Hole 518. In addition to pink $G$. ruber, the assemblages also contain pink Globigerina rubescens and typical large right-coiling Globorotalia hirsuta. Single specimens of $G$. theyeri appear in the upper part of the interval, and $G$. inflata var. disappears in the middle of the interval. The species has a restricted range in the Pleistocene sediments (Barash, 1971); it disappeared in the North Atlantic during the last strong cooling (Oxygen Isotopic Stage 2).

The LAD of G. menardii (tumida) flexuosa occurs in the upper part of the interval at both sites. Bolli and Premoli Silva (1973) used this phenomenon to define the upper boundary of Globigerina calida calida Subzone, establishing its age as $80,000 \mathrm{yr}$. Similar estimates of the LAD level of $G$. menardii flexuosa in the Atlantic Ocean have also been made (Ericson et al., 1964; Emiliani, 1971; and Emiliani and Shackleton, 1974; Bé et al., 1976). The analysis of many dozens of Pleistocene cores, subdivided by the usual climatic-stratigraphic method and supported by radiocarbon dating, reveals the later extinction of this species in the Atlantic (about 25,000 yr. ago, during the Oxygen Isotopic Stage 2). Our paleotemperature curve for Site 516 does not reveal the last cold-water stage corresponding to Oxygen Isotopic Stage 2. This absence can be apparently explained by drilling disturbance of the primary stratigraphy of the uppermost soft sediment. Stage 2 is, however, distinct on the curve for Core L-878 (Fig. 2). The extinction of $G$. menardii flexuosa during the last cooling is dated in Core L-878 by radiocarbon method at approximately 23,000 yr. ago. During Oxygen Isotopic Stage 3, its habitat was considerably restricted and its abundance diminished, compared to Stage 5 . This restriction seems to explain the supposed $G$. menardii flexuosa extinction at the end of the warm-water Stage 5 .

Bolli and Premoli Silva (1973) define the subzones of Globigerina bermudezi as the interval from the LAD of Globorotalia menardii (tumida) flexuosa to the FAD of G. fimbriata (approximately 11,000 yr. ago). Because both Globigerina bermudezi and Globorotalia fimbriata were not recovered in the sediment from the Rio Grande province, the uppermost subzone of G. fimbriata is undefined.

\section{QUATERNARY PALEOTEMPERATURES OF THE SURFACE WATER IN THE RIO GRANDE RISE REGION}

Planktonic foraminifers from both sites are subtropical complexes throughout the Quaternary, indicating relatively stable conditions (in particular, stable temperature of the upper water layer). Species ratios in cores from Hole 516 correspond to our IIIc to IIIe subtypes, and those from Hole 518 to Subtypes IIId and IIIe of our subtropical thanatocoenosis type (Figs. 2-3).

In both sites, the FAD of Globorotalia truncatulinoides occurs in the warm-water interval between two weak cold-water peaks. The average annual temperature and temperature fluctuations during the accumulation of $G$. crassaformis viola interval are lower in Hole 516 than Hole 518. The pattern was apparently the same during the accumulation of the $G$. crassaformis hessi interval, except that temperature fluctuations were small at both sites.

At the base of the Globigerina calida calida interval, cooling is observed in both holes. The average temperature during the accumulation of this faunal interval (in Hole 516) was the minimum of the entire Quaternary period (i.e., $20.8^{\circ} \mathrm{C}$ ). In Hole 518 , it was $21.4^{\circ} \mathrm{C}$. Distinct cold and warm peaks with $3^{\circ} \mathrm{C}$ difference between them were reconstructed from Hole 516. The general trend toward a continuous gradual increase in the medial temperature (average between the peaks) is obvious.

The last interval, Globigerinoides ruber pink, on the whole, is characterized by warmer conditions at both sites. No temperature fluctuations are found within this interval in Hole 516, because of the reworking and sediment mixing during the coring process.

The paleotemperature curve plotted for Core L-878 (Fig. 2), obtained in the same region as Site 516, however, shows intervals corresponding to Oxygen Isotopic Stages 1 to 4 (the two stadial horizons of the last glaciation, $\sim 20^{\circ} \mathrm{C}$; the interstadial; and the Holocene, $\sim 22^{\circ} \mathrm{C}$ ). In Hole 518 , sharp temperature fluctuations within the last interval correspond to the general pattern recorded in Core L-878 (compare Figs. 2 and 3).

In Hole 518, the earlier climatic stages are not so distinct because of partial dissolution and redeposition of the sediment. In Hole 516, however, in the Globigerina calida calida interval, four cold-water events can be detected that seem to correspond to the Oxygen Isotopic Stages 10,12, 14, and 16 .

Cold intervals discovered on the reconstructed paleotemperature curves can be attributed to the classic Alpine glaciations (Fig. 2). In Hole 516, the two cold-water intervals in the lower Pleistocene seem to correspond to the phases of Donau Glaciation (Nikiforova, 1980), and the cold-water peak at $5.3 \mathrm{~m}$ sub-bottom to the Gunz (Stage 22). Peaks at the depths of 3.75, 3.2, and $2.3 \mathrm{~m}$ correlate with the Oxygen Isotopic Stages 16, 14, and 12 , and are attributed to the phases of Mindel Glaciation, which continued from 600,000 to $350,000 \mathrm{yr}$. ago (Cooke, 1973). The lower of these peaks seems to reflect the cooling in the middle of Günz-Mindel Interglacial 
(Cromer), approximately 600,000 yr. ago (Nikiforova, 1980).

Peaks correlating with Stages 6 and 8 (Site 516) represent the Riss stadials, and a peak attributed to Stage 10 (Site 516) falls within the Mindel-Riss Interglacial (according to the scheme by K. V. Nikiforova, 1980). Here, Cooke (1973) recognizes a short glacial interval, but Kukla (1977) includes cold Stages 8, 10, and 12 in the Riss Glacial. Hole 518 also contains the Würm (Stages 4 to 2) and Holocene (Stage 1).

Comparison of the LADs of planktonic foraminiferal species to the paleotemperature curves indicates their correlation to the cool intervals. Subtropical zones of the Atlantic during the Pleistocene have minimal temperature fluctuations. Thus, the temperature fluctuations, reconstructed at Site 516, reflect more significant temperature and hydrologic changes occurring in other oceanic regions. Disappearance, during the cold Pleistocene intervals, of some species evolved during the generally warm Pliocene, is an ecological result of the gradual progressive cooling.

\section{SEDIMENTATION AND BOTTOM WATER CIRCULATION IN THE RIO GRANDE RISE REGION}

Location of the sites on the Rio Grande Rise permits differentiation of the patterns of sedimentation and of bottom water circulation near the crest of the Rise and on its lower slope in the Vema Channel. The composition of planktonic foraminiferal assemblages, foraminiferal number, preservation, and the planktonic-benthic foraminiferal ratio are most useful for this purpose.

Our analyses for Hole 516 do not demonstrate a distinct correlation between the number of shells and paleotemperatures. Intervals with high concentrations of shells correspond more often to cold-water periods. This correspondence can result from the reduction of the shell size during cold intervals and/or from the reduction of the coccolith input into the sediment.

In Hole 518, the foraminiferal number is considerably less than in Hole 516. This difference testifies to the partial dissolution of the assemblages or to the increase in the coccolith inflow to the sediment. In any case, and in contrast to the pattern at Hole 516, curves for the foraminiferal number and for paleotemperature are directly correlated (Fig. 3). Dissolution is perhaps correlated with increased production of and consequent uplift of the Weddell Sea Deep Water or AABW. The transition zone between NADW and AABW presently lies between 4000 and $4200 \mathrm{~m}$ depth, only several tens of meters deeper than Hole 518. The northward flow of AABW, which is both cold and corrosive to $\mathrm{CaCO}_{3}$, through the Vema Channel is expected to increase during cold intervals. Our dissolution curve is perhaps, therefore, a record of the pulses of AABW flow. In contrast, planktonic foraminiferal assemblages from Hole 516 do not preserve this dissolution signal, primarily because Site 516 falls within the area of the Upper Circumpolar Water ( $200 \mathrm{~m}$ below Antarctic Intermediate Water). As previously stated, fluctuations in the relative concentration of benthic foraminifers could result from the depth vari-
Table 2. Sedimentation rates at Hole 518.

\begin{tabular}{lccc}
\hline $\begin{array}{c}\text { Horizon } \\
\text { (subzone) }\end{array}$ & $\begin{array}{c}\text { Duration } \\
\text { (in Ma) }\end{array}$ & $\begin{array}{c}\text { Thickness } \\
\text { (in m) }\end{array}$ & $\begin{array}{c}\text { Rate } \\
\text { (in cm/ } \\
\text { thousand years) }\end{array}$ \\
\hline $\begin{array}{l}\text { Globigerinoides ruber pink } \\
\text { Globigerina calida calida }\end{array}$ & 0.28 & 2.25 & 0.84 \\
$\begin{array}{l}\text { Globorotalia crassaformis } \\
\text { hessi }\end{array}$ & 0.53 & 2.40 & 0.45 \\
$\begin{array}{l}\text { Globorotalia crassaformis } \\
\text { viola }\end{array}$ & 0.43 & 6.10 & 0.92 \\
\hline
\end{tabular}

ation of the transition zone separating these two water masses.

Hole 518 contains layers of a redeposited sediment at depths 8.75-9.95 and 15.7-16.3 m sub-bottom. Taking into account both the age of $G$. truncatulinoides (1.9 $\mathrm{Ma}$ ) and interpolating the ages of the boundaries between the four biostratigraphic horizons, we can estimate the sedimentation rates at Hole 518 (Table 2).

Average rates of sedimentation during the entire $G$. truncatulinoides horizon at Hole 516 is $0.52 \mathrm{~cm} /$ thousand years compared to $0.84 \mathrm{~cm} /$ thousand years at Hole 518 (1.6 times higher). This difference results from the dominant deposition of fine carbonate debris, in particular, coccoliths, on the flank of the Rio Grande Rise, not on its crest, where hydrodynamic activity might be stronger. The rate of the Quaternary sedimentation at Site 518 is slightly lower than during the Recent in the same region (1.0-3.0 cm/thousand years, Lisitzin, 1972).

\section{ACKNOWLEDGMENTS}

We thank Dr. Peter Barker, Dr. Richard Carlson, and Dr. David A. Johnson, Co-chief Scientists of DSDP Leg 72, and Dr. William T. Coulbourn, Scientific Staff Representative of DSDP, for sending us samples, and we are grateful to Prof. Alexander P. Lisitzin, chief of the Marine Geology Department, Institute of Oceanology, Academy of Sciences USSR, for his support of this work. We are especially indebted to William Coulbourn for a thorough editing of the English version of this paper.

\section{REFERENCES}

Banner, F. T., and Blow, W H., 1965. Progress in planktonic foraminiferal biostratigraphy of the Neogene. Nature, 208(5106):1164.

Barash, M. S., 1964. The stratigraphy and foraminifera of the sediments of the North Atlantic. Byull. Mosk. Ob. Ispyt. Prir. Otd. Geol., 6:148.

1970. Planktonnyye Foraminifery v Osadkach Severnoy Atlantiki (The Planktonic Foraminifers in the Sediments of the North Atlantic): Moscow (Nauka).

1971. The vertical and horizontal distribution of planktonic foraminifera in Quaternary sediments of the Atlantic Ocean. In Funnell, B. M., and Riedel, W. R. (Eds.), The Micropaleontology of Oceans: London (Cambridge University Press), pp. 433-441. 1974. Migrations of climatic belts of the Atlantic Ocean during the late Quaternary. Dokl. Akad. Sc. USSR, 216(5):1158-1160. 1981. Climatic zonality of the Atlantic Ocean during the Quaternary. In Lisitzin, A. P., and Guershanovich, D. E. (Eds.), Klimaticheskaya zonalnost i osadkoobrazovaniye (Climatic Zonality And Sedimentation): Moscow (Nauka), pp. 126-139.

Barash, M. S., and Blyum, N. S., 1974. The distribution of species of planktonic foraminifers in the sediments of the North Atlantic as a function of water temperature. In Jousé, A. P. (Ed.), Mikropaleontologiya morey $i$ okeanov (Micropaleontology of Seas and Oceans): Moscow (Nauka), pp. 138-149.

1975. Modern thanatocoenoses of planktonic foraminifers in the North and Equatorial Atlantic. Oceanology Engl. Transl., 15(1):108-115. 
Barash, M. S., and Okuneva, O. G., 1981. On late Quaternary paleotemperature oscillations in the North Atlantic tropical zone (based on planktonic foraminifera). Oceanology Engl. Transl., 21(5): 845-854.

Barash, M. S., and Os'kina, N. S., 1979. Paleotemperatures of the Atlantic Ocean 18,000 and 40,00 years ago (based on planktonic foraminifera). Oceanology Engl. Transl., 19(1):93-101.

Barash, M. S., Os'kina, N. S., and Ivanova, E. V., 1980. The NearAfrican upwellings in late Pleistocene from the data on planktonic foraminifera. Oceanology Engl. Transl., 20(1):97-105.

Barker, P. F., Carlson, R. L., Johnson, D. A., and Shipboard Scientific Party, 1981. Deep Sea Drilling Project Leg 72: Southwest Atlantic paleocirculation and Rio Grande Rise tectonics. Bull. Geol. Soc. Am., 92:294-309.

Bé, A. W. H., 1977. An ecological, zoogeographic and taxonomic review of Recent planktonic Foraminifera. In Ramsay, A. T. F. (Ed.), Oceanic Micropaleontology (Vol. 1): London (Academic Press), 1-88.

Bé, A. W. H., Damuth, J. E., Leroy, L., and Free, R., 1976. Late Quaternary climatic record in western equatorial Atlantic sediment. In Cline, R. M., and Hays, J. D. (Eds.), Investigation of Late Quarternary Paleoceanography and Paleoclimatology: Boulder, CO (Geol. Soc. Am. Mem.), 145:165-200.

Berger, W. H., 1968. Planktonic foraminifera: selective solution and paleoclimatic interpretation. Deep-Sea Res., 15(1):31-43.

1970. Planktonic foraminifera: selective solution and the lysocline. Mar. Geol., 8:111-138.

Berggren, W. A., Burckle, L. H., Cita, M. B., Cooke, H. B. S., Funnell, B. M., Gartner, S., Hays, J. D., Kennett, J. P., Opdyke, N. D. Pastouret, L., Shackleton, N. J., and Takayanagi, Y., 1980. Towards a Quaternary time scale. Quat. Res., 13:217-302.

Berggren, W. A., and Van Couvering, J., 1974. The late Neogene: biostratigraphy, biochronology, and paleoclimatology of the last 15 million years in marine and continental sediments. Palaeogeogr. Palaeoclimatol. Palaeoecol., 16(1-2):1-216.

Blow, W. H., 1969. Late middle Eocene to Recent planktonic foraminiferal biostratigraphy. In Brönniman, P., and Renz, H. H. (Eds.) Proc. First Int. Conf. Planktonic Microfossils, Geneva, 1967: Leiden (E. J. Brill),

Bolli, H. M., and Premoli Silva, I., 1973. Oligocene to Recent planktonic foraminifera and stratigraphy of the Leg 15 sites in the Caribbean Sea. In Edgar, N. T., Saunders, J. B., et al., Init. Repts. DSDP, 15: Washington (U.S. Govt. Printing Office), 475-498.

CLIMAP Project Members, 1976. The surface of the ice-age Earth. Science, 191:1131-1137.

1981. Seasonal reconstructions of the Earth's Surface at the Last Glacial Maximum. Geol. Soc. Am. Map and Chart Series, MC-36.

Cline, R. M., and Hays, J. D. (Eds.), 1976. Investigation of Late Quaternary Paleoceanography and Paleoclimatology: Boulder, CO (Geol. Soc. Am. Mem.), 145.

Cooke, H. B. S., 1973. Pleistocene chronology: long or short? Quat. Res., 3(2):206-220.

Emiliani, C., 1971. The Last Interglacial: paleotemperatures and chronology. Science, 171:571-573.

Emiliani, C., and Shackleton, N. J., 1974. The Brunhes Epoch: isotopic paleotemperatures and geochronology. Science, 183:511-514.

Ericson, D. B., Ewing, M., and Wollin, G., 1964. The Pleistocene Epoch in deep-sea sediments. Science, 146(3645):723-732.

Hecht, A. D., 1973a. A model for determining Pleistocene paleotemperatures from planktonic foraminiferal assemblages. Micropaleontology, 19:68-77.

1973b. Faunal and oxygen isotopic paleotemperatures and the amplitude of glacial-interglacial temperature changes in the Equatorial Atlantic, Caribbean Sea and Gulf of Mexico. Quat. Res., 3(4):671-690.

Imbrie, J., and Kipp, N. G., 1971. A new micropaleontological method for quantitative paleoclimatology: application to a late Pleistocene Caribbean core. In Turekian, K. K. (Ed.), The Late Cenozoic Glacial Ages: New Haven (Yale University Press), pp. 71-181.

Kipp, N. G., 1976. New transfer function for estimating past sea-surface conditions from sea-bed distribution of planktonic foraminif- eral assemblages in the North Atlantic. In Cline, R. M., and Hays, J. D. (Eds.), Investigation of Late Quaternary Paleoceanography and Paleoclimatology: Boulder, CO (Geol. Soc. Am. Mem.), 145: $3-42$.

Krasheninnikov, V. A., 1977. Importance of oceanic deposits for elaboration of the Mesozoic and Cenozoic stratigraphic scale (Indian Ocean). Vopr. Mikropaleontol., 19:124-226.

1978. Importance of oceanic deposits for elaboration of the Mesozoic and Cenozoic stratigraphic scale (Pacific and Atlantic Oceans). Vopr. Mikropaleontol., 21:42-161.

1979a. Stratigraphy, by means of planktonic foraminifers, of Neogene and Quaternary sediments near the crest of the MidAtlantic Ridge, DSDP Sites 395 and 396. In Melson, W. G., Rabinowitz, P. D., et al., Init. Repts. DSDP, 45: Washington (U.S. Govt. Printing Office), 319-322.

$1979 b$. Stratigraphy and planktonic foraminifers of Neogene and Quaternary sediments of Site 396, Leg 46 of DSDP. In Dmitriev, L., Heirtzler, J., et al., Init. Repts. DSDP, 46: Washington (U.S. Govt. Printing Office), 409-413.

Krasheninnikov, V. A., and Pflaumann, U., 1978. Zonal stratigraphy of Neogene deposits of the eastern part of the Atlantic Ocean by means of planktonic foraminifers, Leg 41, Deep Sea Drilling Project. In Lancelot, Y., Seibold, E., et al., Init. Repts. DSDP, 41: Washington (U.S. Govt. Printing Office), 613-657.

Kukla, G. J., 1977. Pleistocene land-sea correlations. I. Europe. EarthSci. Rev., 13(4):307-374.

Lisitzin, A. P., 1972. Sedimentation in the Ocean: Tulsa, OK (Soc. Econ. Paleontol. Mineral. Spec. Publ.), 17:1-218.

Lynts, G. W., and Judd, J. B., 1971. Late Pleistocene paleotemperatures at Tongue of the Ocean, Bahamas. Science, 171:1143-1144.

Morley, J. J., and Hays, J. D., 1981. Towards a high-resolution, global, deep-sea chronology for the last 750,000-years. Earth Planet. Sci. Lett., 53:279-295.

Nikiforova, K. V., 1980. Chronostratigraphy of the upper Pliocene and the Quaternary. Stratigraphy in Investigations of the Geological Institute of the Academy of Science of the USSR: Moscow (Nauka), pp. 254-258.

Parker, F. L., 1967. Late Tertiary biostratigraphy (planktonic foraminifera) of tropical Indo-Pacific deep-sea cores. Bull. Am. Paleontol., 52(235):115-208.

Reid, J. L., Nowlin, W. D., and Patzert, W. C., 1977. On characteristics and circulation of the southwestern Atlantic Ocean. J. Phys. Oceanogr., 7:72-91.

Rögl, F., 1974. The evolution of the Globorotalia truncatulinoides and Globorotalia crassaformis group in the Pliocene and Pleistocene of the Timor Trough, DSDP Leg 27, Site 262. In Veevers, J. J., Heirtzler, J. R., et al., Init. Repts. DSDP, 27: Washington (U.S. Govt. Printing Office), 743-768.

Schott, G., 1944. Geographie des Atlantischen Ozeans: Hamburg (C. Boysen).

Shackleton, N. J., and Opdyke, N. D., 1973. Oxygen isotope and paleomagnetic stratigraphy of Equatorial Pacific cores V28-238: oxygen istope temperatures and ice volumes on a $10^{5}$ year and $10^{6}$ year scale. Quat. Res., 3:39-55.

1976. Oxygen-isotope and paleomagnetic stratigraphy of Pacific Core V28-239 late Pliocene to latest Pleistocene. In Cline, R. M., and Hays, J. D. (Eds.), Investigation of Late Quaternary Paleoceanography and Paleoclimatology: Boulder, CO (Geol. Soc. Am. Mem.), 145:449-464.

Van Donk, J., 1976. $\mathrm{O}^{18}$ record of the Atlantic Ocean for the entire Pleistocene Epoch. In Cline, R. M., and Hays, J. D. (Eds.), Investigation of Late Quaternary Paleoceanography and Paleoclimatology: Boulder, CO (Geol. Soc. Am. Mem.), 145:147-164.

Vincent, E., Frerichs, W. E., and Heiman, M. E., 1974. Neogene planktonic foraminifera from the Gulf of Aden and the western tropical Indian Oceans, Deep Sea Drilling Project, Leg 24. In Fisher, R. L., Bunce, E. T., et al., Init. Repts. DSDP, 24: Washington (U.S. Govt. Printing Office), 827-849.

Date of Initial Receipt: April 22, 1982 

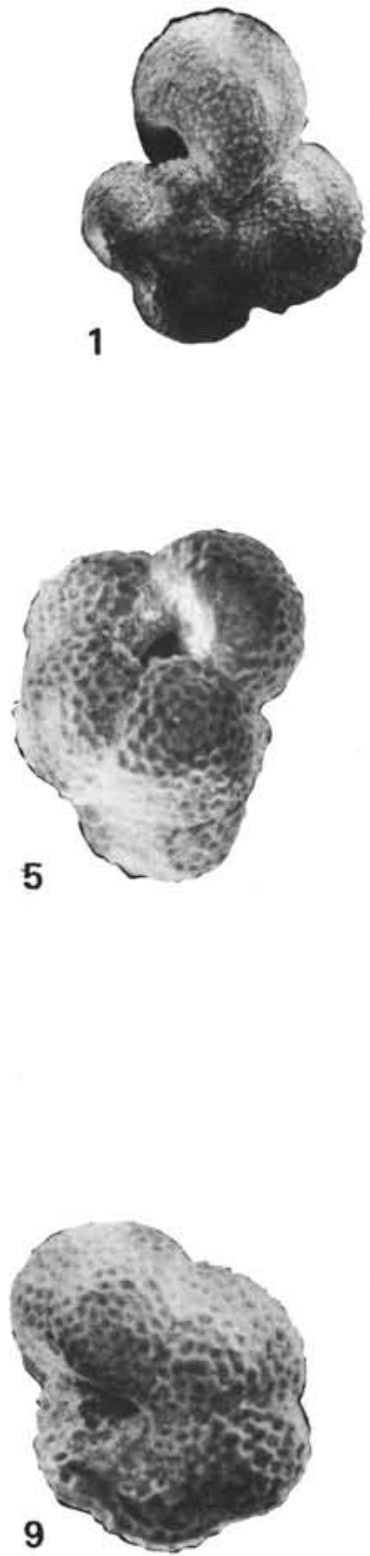
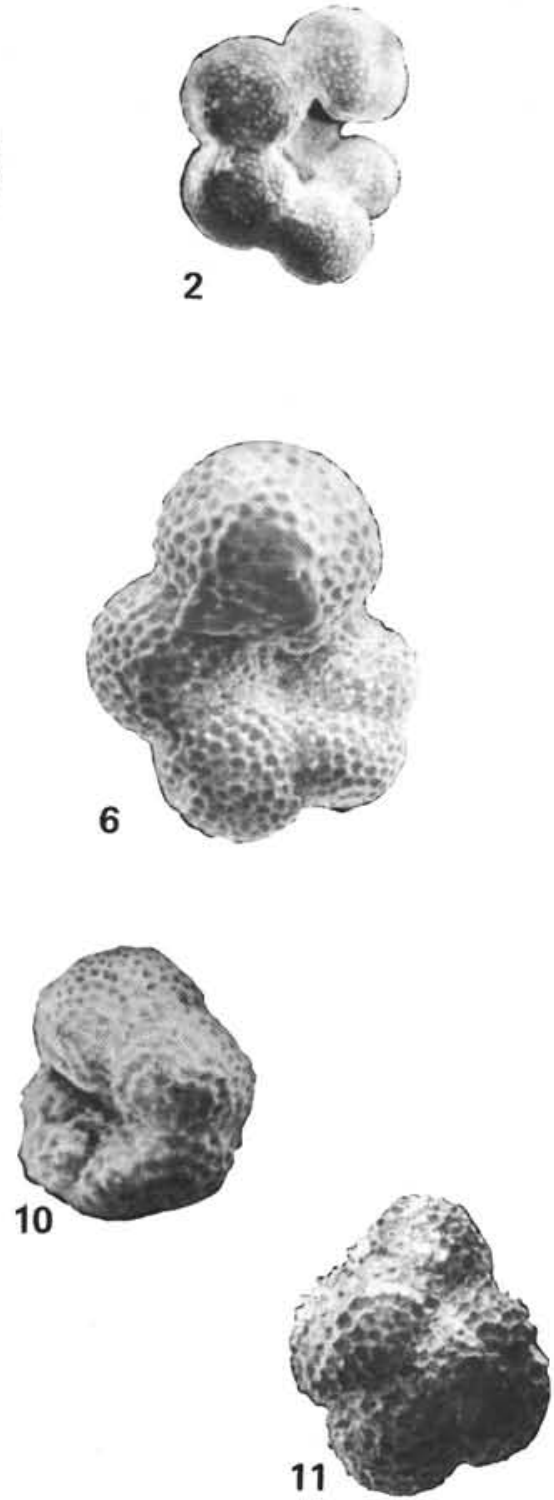
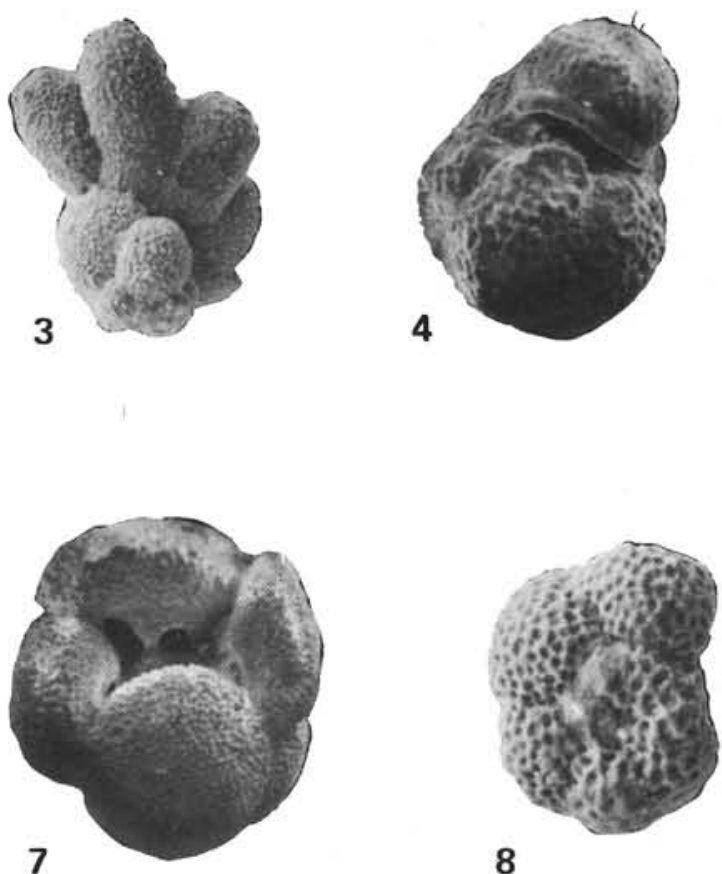

8
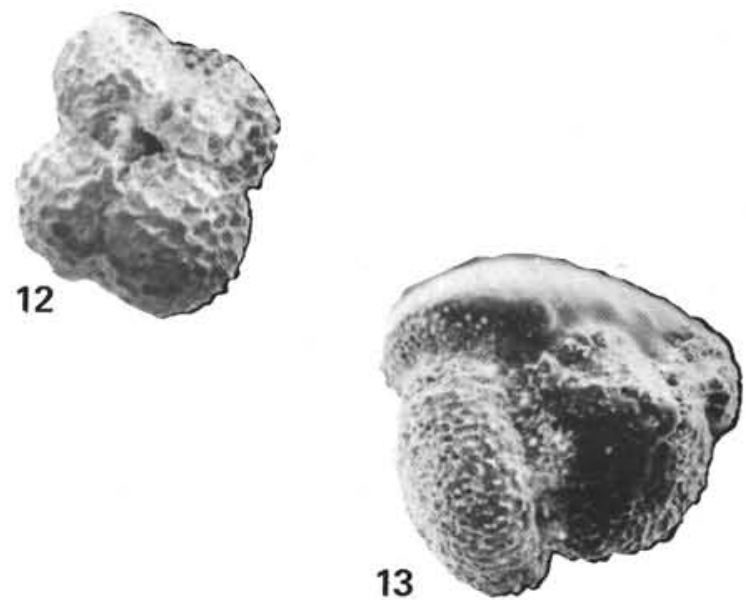

Plate 1. (All specimens magnified $\times 50$ unless otherwise specified.) 1. Globigerina calida calida Parker, Sample 518-2-3, 65-67 cm. 2. Globigerina calida praecalida Blow, Sample 518-3-3, 67-69 cm. 3. Globigerina digitata Brady, Sample 518-3-1, 136-142 cm. 4. Globigerina nepenthes Todd, Sample 518-5-1, 110-117 cm, $\times 70$. 5. Globigerina decoraperta Takayanagi and Saito, Sample 518-5-1, 133-135 cm, $\times 100$. 6. Globoquadrina hexagona (Natland), Sample 518-2-2, 71-72 cm, $\times 100$. 7. Globoquadrina altispira (Cushman and Jarvis), Sample 518-5-1, 10-12 cm, $\times 40$. 8-10. Globoquadrina acostaensis (Blow), (8) spiral view, Sample 516-3-2, 93-95 cm, $\times 100,(9-10)$ umbilical view, Sample 516-3-2, 93-95 $\mathrm{cm}, \times 100$. 11-12. Sphaeroidinellopsis seminulina (Schwager), (11) spiral view, Sample 518-5-1, 110-117 cm, $\times 40$, (12) umbilical view, Sample 518-5-1, 73-75 cm. 13. Globigerinoides obliquus Bolli, Sample 518-3-1, 103-105 cm. 

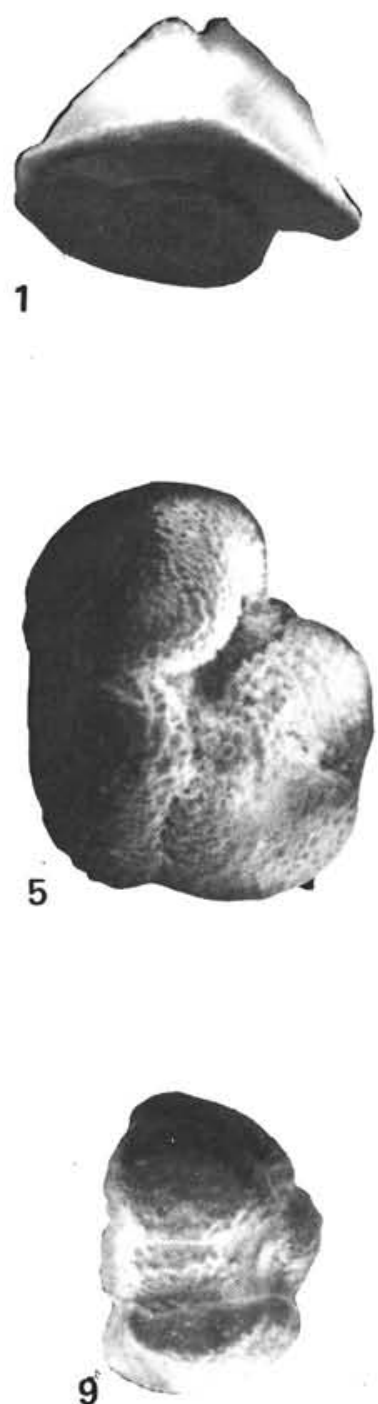
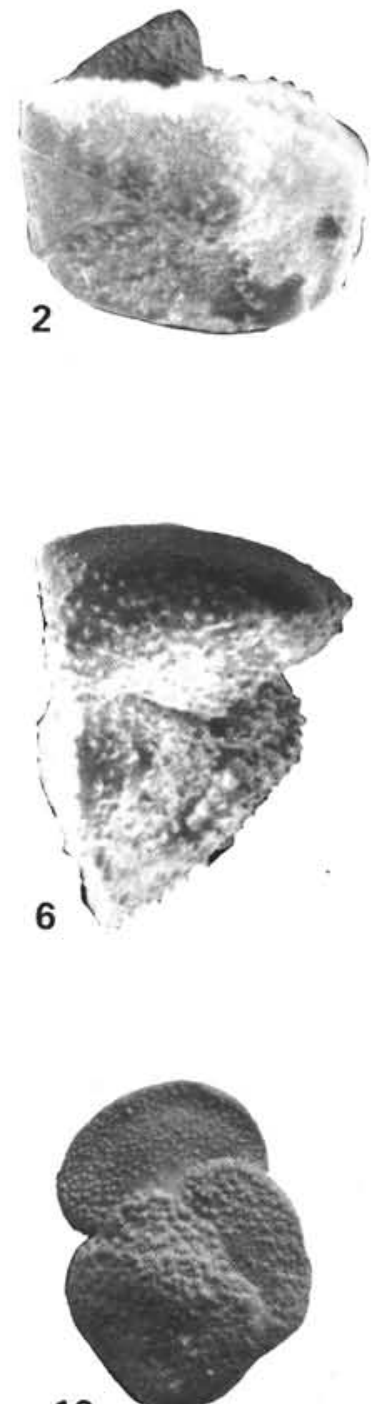

10
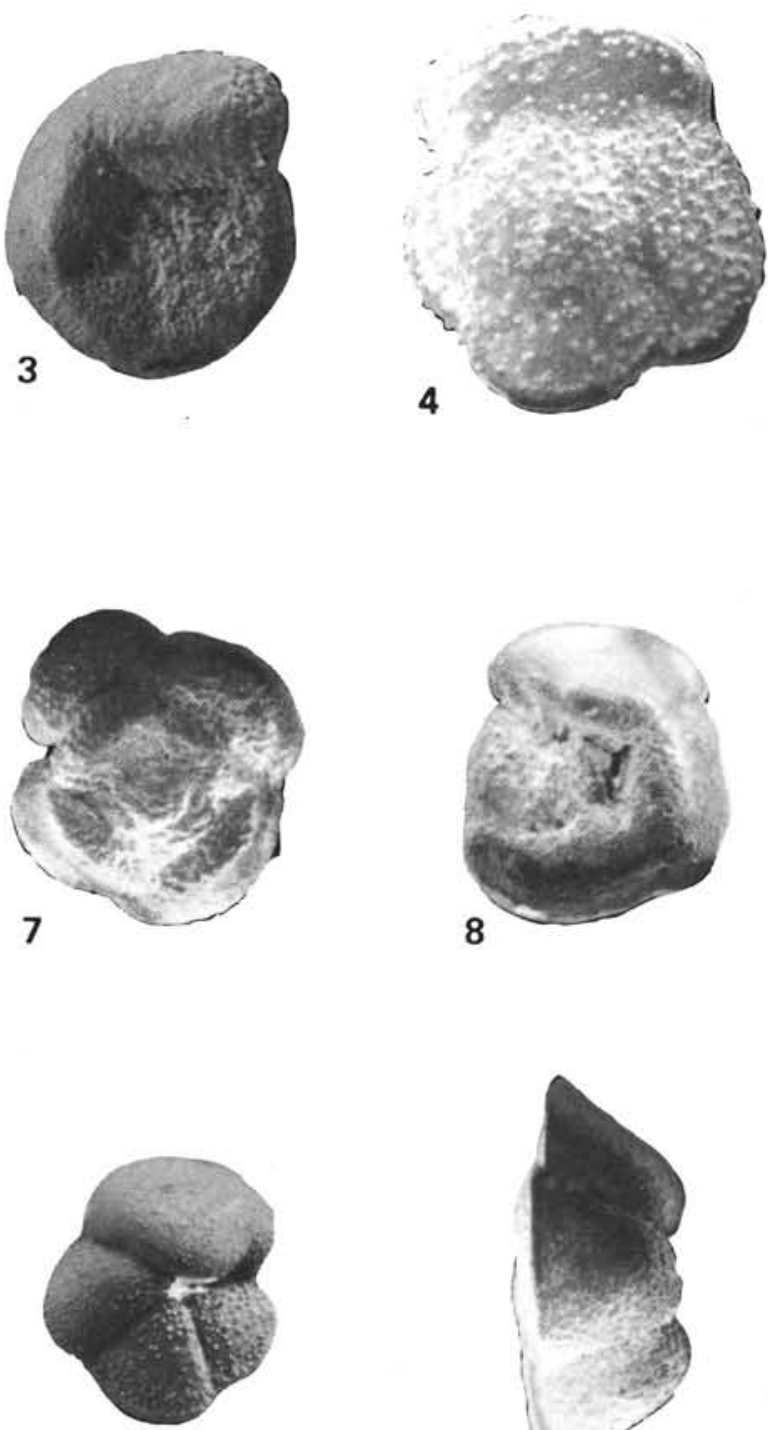

11

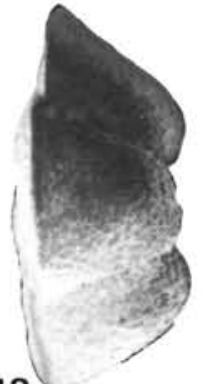

12

Plate 2. (All specimens magnified $\times 70$ unless otherwise indicated.) 1. Globorotalia truncatulinoides (d'Orbigny), Sample 518-1-1, 43-45 cm, $\mathrm{N} 23$, Globigerinoides ruber pink interval, $\times 50$. 2. Globorotalia truncatulinoides (d'Orbigny), Sample 516-3-3, 145-147 cm, N22, Globorotalia crassaformis viola interval. 3. Globorotalia tosaensis Takayanagi and Saito, Sample 516-3-1, 55-57 cm, $\times 60$. 4-6. Globorotalia crassaformis crassaformis (Galloway and Wisler), (4) spiral view, Sample 518-2-2, 71-72 cm, (5) umbilical view, Sample 516-2-1, 52-54 cm, (6) side view, Sample 518-3-1, 22-24 cm. 7-9. Globorotalia crassaformis hessi Bolli and Premoli Silva. (7) spiral view, Sample 516-2-3, 3-10 cm. $\times 40,(8)$ umbilical view, Sample 518-3-1, 59-65 cm, $\times 30$, (9) side view, Sample 516-2-3, 3-10 cm, $\times 40 . \quad 10-12$. Globorotalia crassaformis viola Blow, (10) spiral view, Sample 516-3-2, 52-54 cm, $\times 40$, (11) umbilical view, Sample 516-3-2, 118-125 cm, $\times 30,(12)$ side view, Sample 518-4,CC, $\times 40$. 

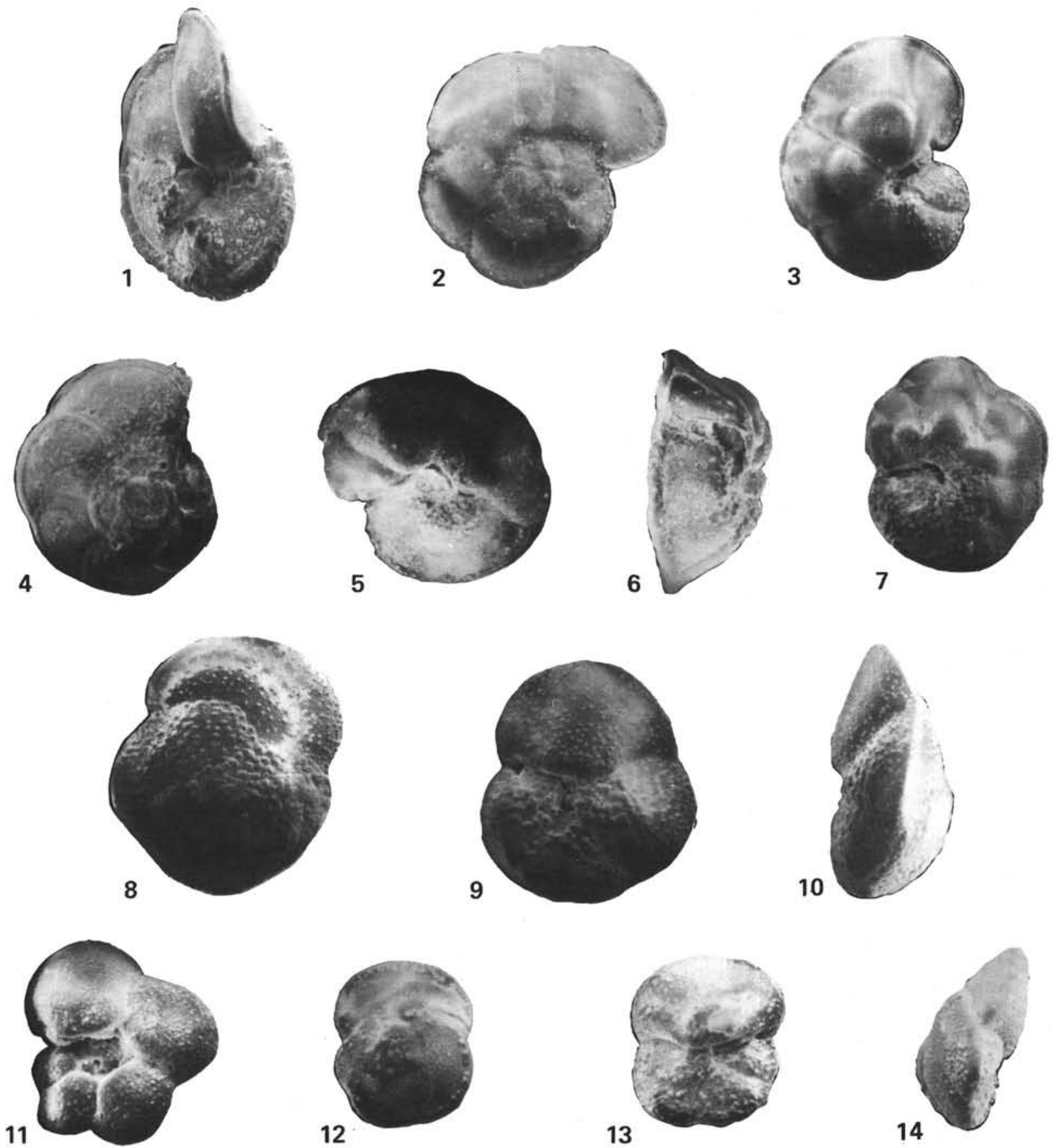

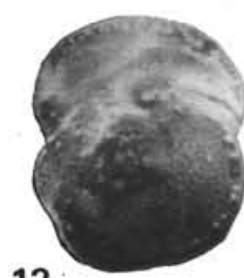

12

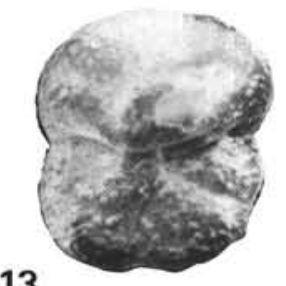

13

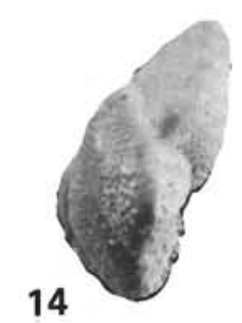

14

Plate 3. (All specimens magnified $\times 50$ unless otherwise indicated.) 1. Globorotalia menardii flexuosa (Koch), Sample 518-1-1, 13-20 cm, $\times 25$. 2-3. Globorotalia exilis Blow, (2) spiral view, Sample 516-3,CC, (3) umbilical view, Sample 518-5-1, 110-117 cm. 4-6. Globorotalia miocenica Palmer, (4) spiral view, Sample 518-5-1, 10-12 cm, x60, (5) umbilical view, Sample 516-3,CC, (6) side view, Sample 516-3,CC. 7. Globorotalia pertenuis Beard, Sample 518-5-1, 73-75 cm. 8-10. Globorotalia hirsuta (d'Orbigny), (8) spiral view, Sample 518-1-1, 43-45 cm, (9) umbilical view, Sample 518-1-1, 43-45 cm, $\times 40,(10)$ side view, Sample $518-1-1,43-45 \mathrm{~cm}, \times 40.11$. Globorotalia theyeri Fleisher, Sample 516-1-1, 40-47 cm, $\times 70$. 12-14. Globorotalia margaritae Bolli and Bermudez, (12) spiral view, Sample 516-3-2, 93-95 cm, $\times 70,(13)$ umbilical view, Sample 516-3-2, 93-95 cm, (14) side view, Sample 518-5-1, 110-117 cm, $\times 70$. 
APPENDIX A

Distribution of Planktonic Foraminiferal Species at Hole $516(\%)$

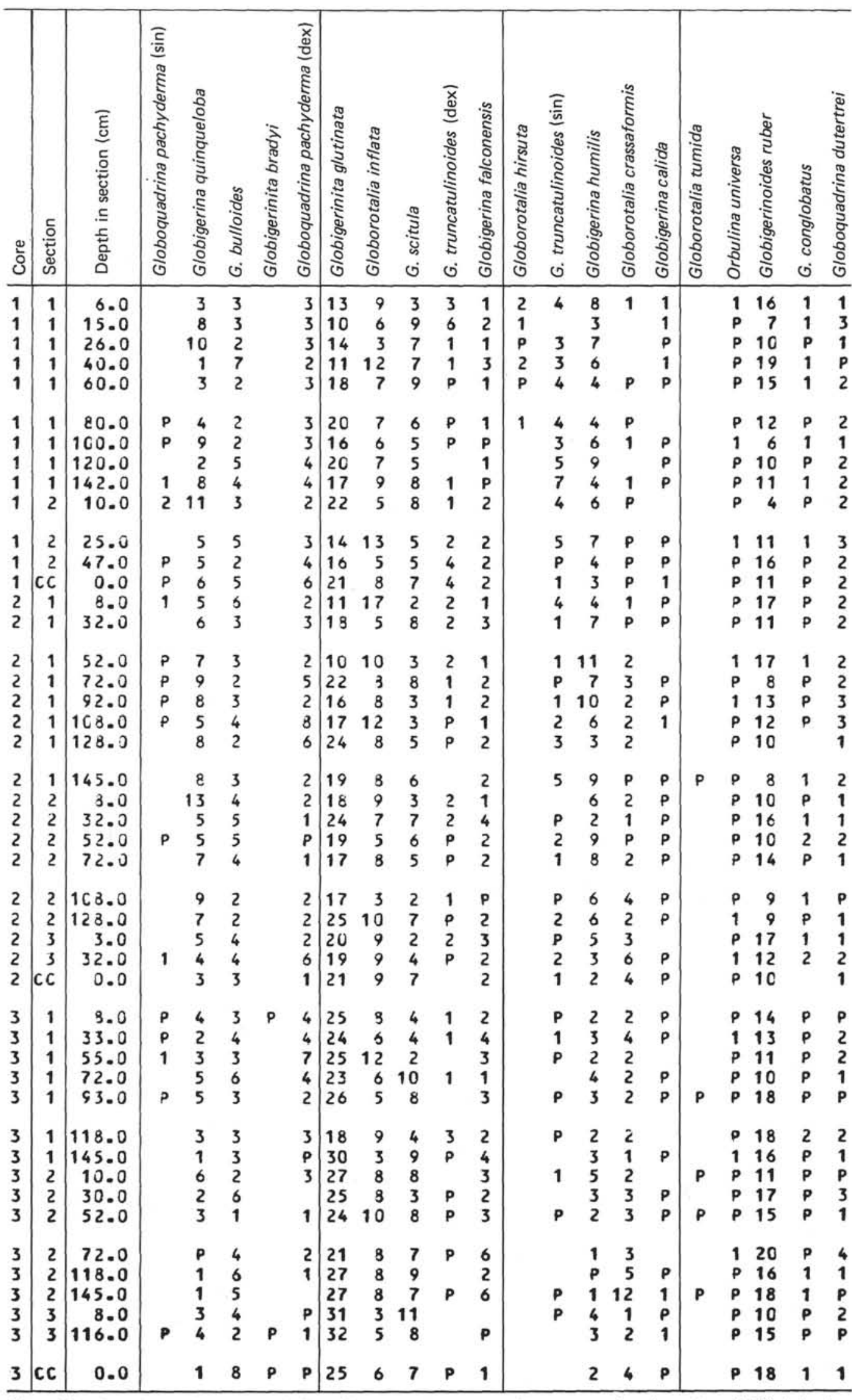

Note: Numbers have been rounded to the nearest percent; $\mathrm{P}=$ present but less than $0.5 \%$; blank = not found. ${ }^{*}=+$ Globigerinoides tenellus; $\sin =$ sinistral (left coiling); dex = dextral (right coiling). 
QUATERNARY BIOSTRATIGRAPHY AND SURFACE PALEOTEMPERATURE

Appendix A. (Continued).

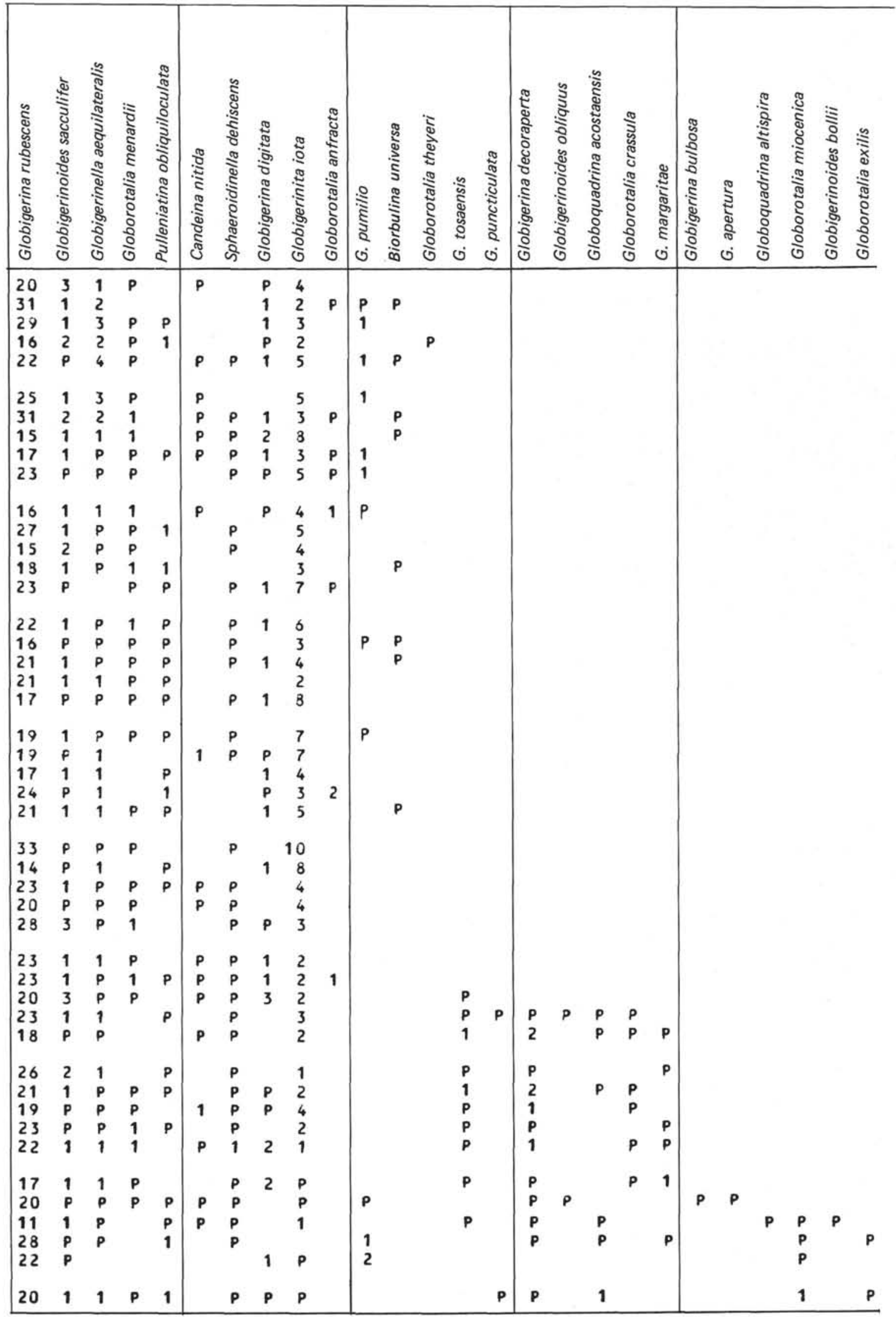




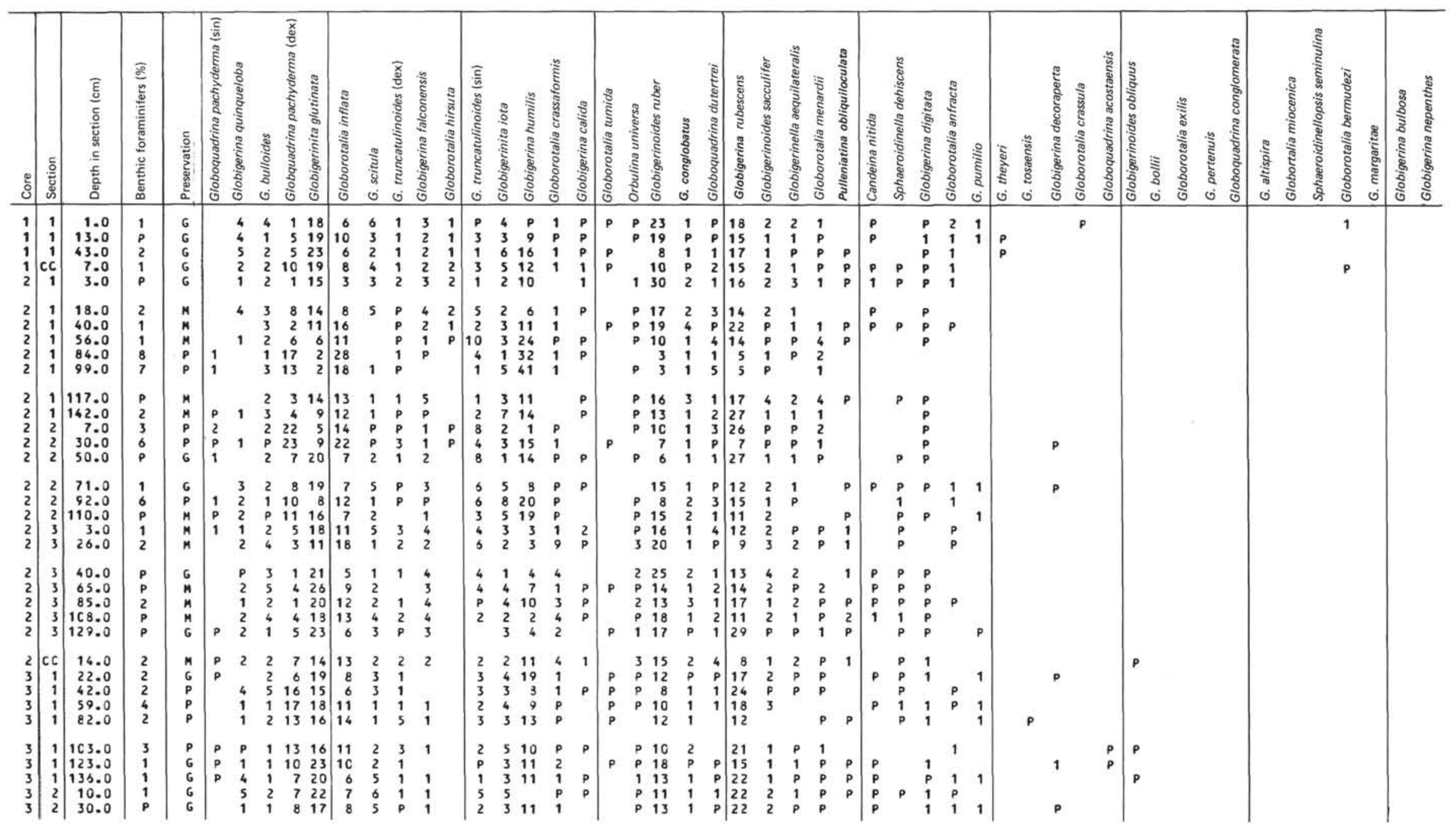

APPENDIX B
Distribution of Planktonic Foraminiferal Species at Hole $518(\%)$ 


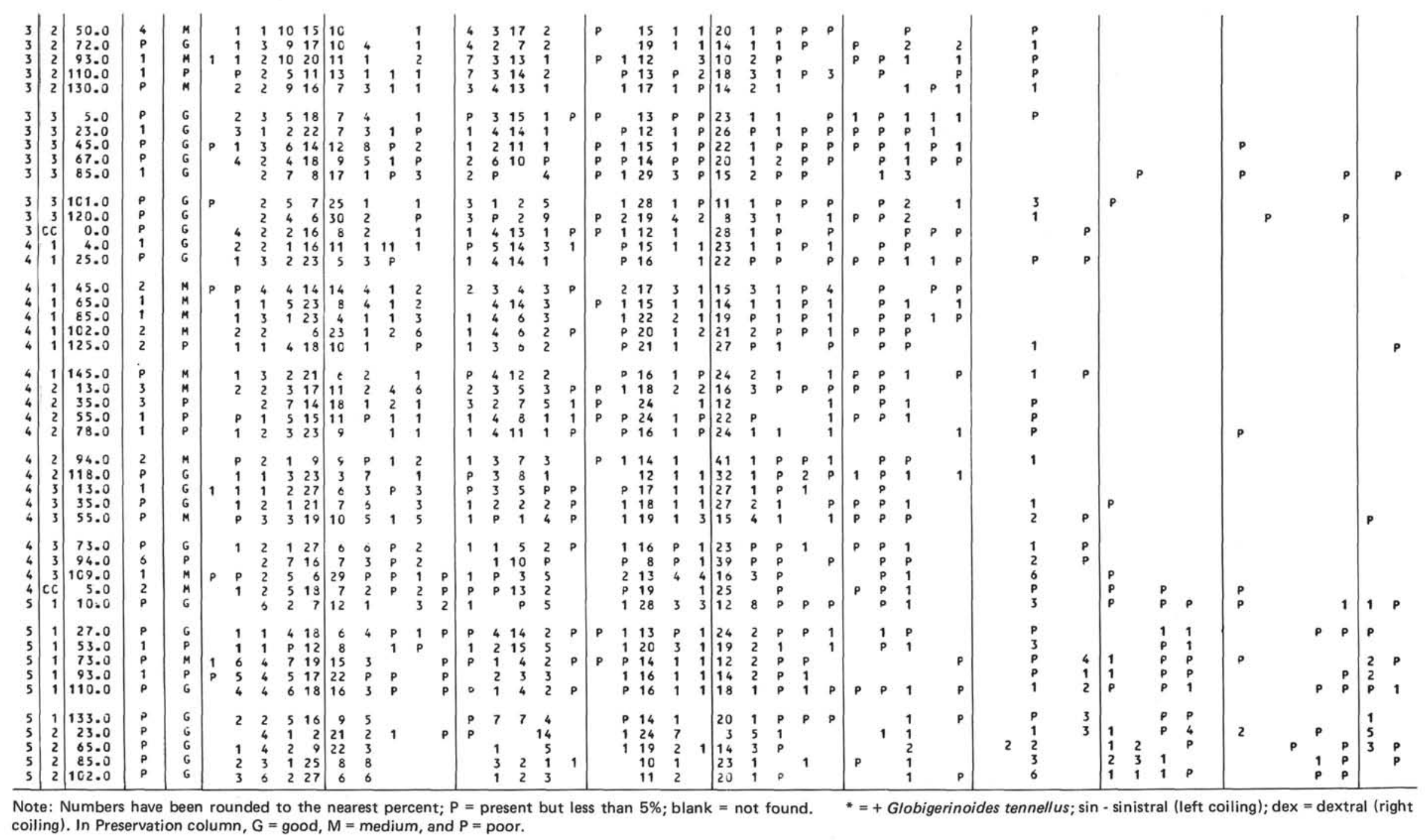

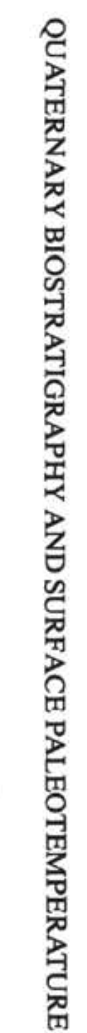

